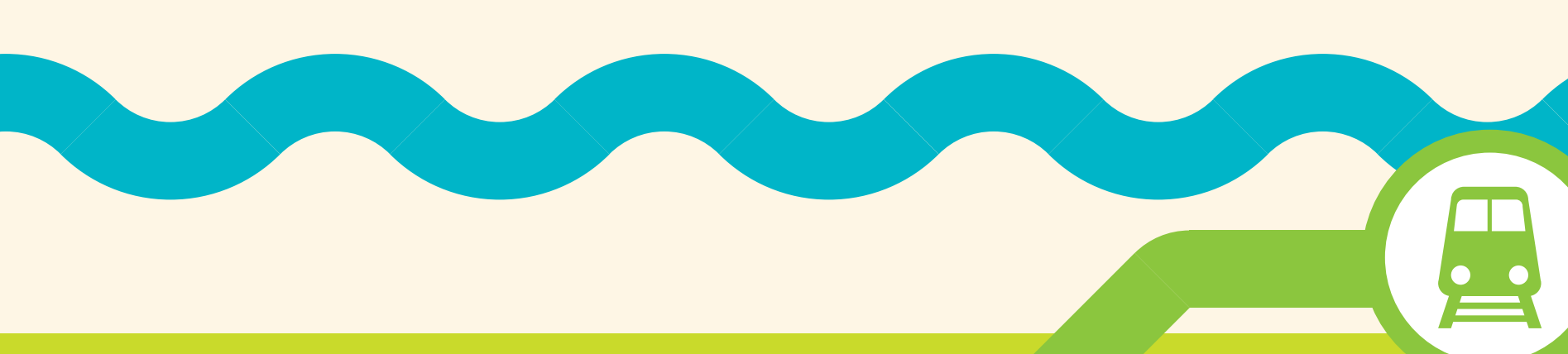

\title{
CAMBODIA TRANSPORT SECTOR ASSESSMENT, STRATEGY, AND ROAD MAP
}

SEPTEMBER 2019 



\section{CAMBODIA TRANSPORT SECTOR ASSESSMENT, STRATEGY, AND ROAD MAP}

SEPTEMBER 2019 
(C) 2019 Asian Development Bank

6 ADB Avenue, Mandaluyong City, 1550 Metro Manila, Philippines

Tel +632632 4444; Fax +6326362444

www.adb.org

Some rights reserved. Published in 2019.

ISBN 978-92-9261-750-9 (print), 978-92-9261-751-6 (electronic)

Publication Stock No. TCS190449-2

DOI: http://dx.doi.org/10.22617/TCS190449-2

The views expressed in this publication are those of the authors and do not necessarily reflect the views and policies of the Asian Development Bank (ADB) or its Board of Governors or the governments they represent.

ADB does not guarantee the accuracy of the data included in this publication and accepts no responsibility for any consequence of their use. The mention of specific companies or products of manufacturers does not imply that they are endorsed or recommended by $\mathrm{ADB}$ in preference to others of a similar nature that are not mentioned.

By making any designation of or reference to a particular territory or geographic area, or by using the term "country" in this document, $A D B$ does not intend to make any judgments as to the legal or other status of any territory or area.

This work is available under the Creative Commons Attribution 3.0 IGO license (CC BY 3.0 IGO)

https://creativecommons.org/licenses/by/3.0/igo/. By using the content of this publication, you agree to be bound by the terms of this license. For attribution, translations, adaptations, and permissions, please read the provisions and terms of use at https://www.adb.org/terms-use\#openaccess.

This CC license does not apply to non-ADB copyright materials in this publication. If the material is attributed to another source, please contact the copyright owner or publisher of that source for permission to reproduce it. $\mathrm{ADB}$ cannot be held liable for any claims that arise as a result of your use of the material.

Please contact pubsmarketing@adb.org if you have questions or comments with respect to content, or if you wish to obtain copyright permission for your intended use that does not fall within these terms, or for permission to use the ADB logo.

Corrigenda to ADB publications may be found at http://www.adb.org/publications/corrigenda.

Notes:

In this publication, “\$” refers to United States dollars.

ADB recognizes "Korea” as the Republic of Korea.

Cover design by Kookie Trivino. 


\section{CONTENTS}

TABLES AND FIGURES IV iv

ACKNOWLEDGMENTS V V

CURRENCY EQUIVALENTS vi

ABBREVIATIONS vi

$\begin{array}{lll}\text { I INTRODUCTION } & 1\end{array}$

II SECTOR ASSESSMENT: CONTEXT AND STRATEGIC ISSUES 2

A. Overall Transport Sector Context
2

B. Subsector Assessments 3

$\begin{array}{ll}\text { C. Core Sector Issues, Causes, and Effects } & 19\end{array}$

$\begin{array}{ll}\text { III SECTOR STRATEGY } & 21\end{array}$

A. Government Sector Strategy and Plans $\quad 21$

B. ADB Sector Support Program and Experience $\quad 22$

C. Other Development Partner Support 22

D. ADB Sector Strategy 23

IV TRANSPORT SECTOR ROAD MAP AND RESULTS FRAMEWORK 30

APPENDIX: PROBLEM TREE FOR TRANSPORT SECTOR 32 


\section{TABLES AND FIGURES}

\section{TABLES}

1 Road Sector Indicators $\quad 4$

2 Programs in the Logistics Strategy 18

3 ADB Loans to the Transport Sector in Cambodia, 1996-2018 23

4 Development Partner Support for Transport Subsectors 24

5 Outline of Current and Future ADB Inputs to the Transport Sector 29

6 Transport Sector Road Map and Results Framework 30

\section{FIGURES}

1 Funding Source for National and/or Provincial Roads, 2014-2018 5

2 Road Fatality Rate $\quad 7$

3 Vehicle Ownership in Cambodia $\quad 7$

4 Maintenance Budget Allocation for National and Provincial Roads 8

5 Maintenance Budget Allocation for Rural Roads 9

6 Railway Freight Traffic Volume 11

7 Logistics Performance Ranking of Cambodia and Its Neighbors, 2010-2018 15

8 Logistics Performance-Cambodia and Its Neighbors 16

9 Strategic Links $\quad 26$ 


\section{ACKNOWLEDGMENTS}

This report was prepared by a team from the Southeast Asia Department (SERD) of the Asian Development Bank led by Takeshi Fukayama, transport specialist. The team members were Shihiru Date, senior transport specialist; Mohammad Nazrul Islam, transport specialist; Margarita M. Javier, senior project assistant; Daisuke Mizusawa, senior transport specialist; Nida Ouk, senior project officer; Ratha Sann, senior project officer (infrastructure); Chaorin Shim, transport specialist; and Gengwen Zhao, transport specialist. Inputs were provided by consultants: Peter J. Darjes and Samnang Hir. Guidance and support were provided by SERD management: Ramesh Subramaniam, director general; F. Cleo Kawawaki, deputy director general; Hiroaki Yamaguchi, director, Transport and Communication Division; and Sunniya Durrani-Jamal, country director, Cambodia Resident Mission.

The team wishes to thank agencies and colleagues in the Government of Cambodia for discussions held during the preparation of the report. 


\section{CURRENCY EQUIVALENTS}

as of 20 July 2019

Currency unit - riel (KR)

$K R 1.00=\$ 0.00024$

$\$ 1.00=K R 4,083.00$

\section{ABBREVIATIONS}

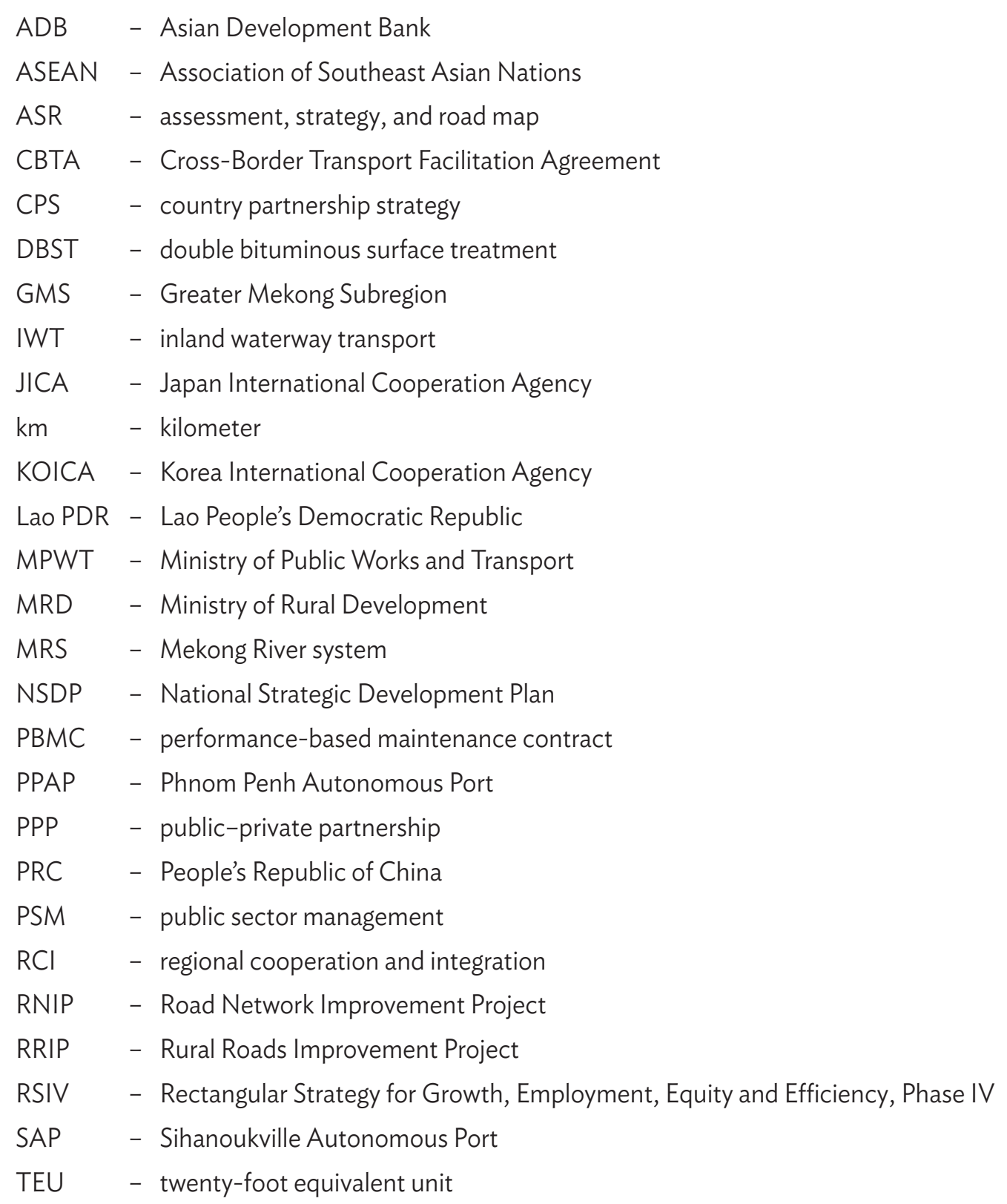




\section{INTRODUCTION}

The Southeast Asia Department of the Asian Development Bank (ADB) is systematically updating sector assessments, strategies, and road maps (ASRs) to better harmonize program and project planning with member countries and development partners. The preparation of this transport ASR is an integral part of project planning to ensure coordination between Cambodia's priorities and those of ADB's Strategy $2030^{1}$ and the ADB Sustainable Transport Initiative. ${ }^{2}$ This sector ASR also provides the basis for dialogue between the Government of Cambodia, the Southeast Asia Department's Transport and Communications Division, and the ADB Cambodia Resident Mission in developing the ADB country partnership strategy (CPS) for Cambodia, 2019-2023. ${ }^{3}$

This ASR on Cambodia's transport sector focuses mainly on roads, railways, and urban transport. The important roles of water transport and air transport are also discussed. Logistics is highlighted as a crosscutting issue. The ASR was developed primarily through consultations with the Ministry of Public Works and Transport (MPWT), which manages the national and provincial road networks and the railways; the Ministry of Rural Development (MRD), which manages rural roads; and development partners working in the transport sector.

ADB. 2018. Strategy 2030: Achieving a Prosperous, Inclusive, Resilient, and Sustainable Asia and the Pacific. Manila.

ADB. 2010. Sustainable Transport Initiative Operational Plan. Manila.

The CPS, 2019-2023 is being processed. 


\section{SECTOR ASSESSMENT: CONTEXT AND STRATEGIC ISSUES}

\section{A. Overall Transport Sector Context}

Cambodia currently has four drivers of growth: agriculture, tourism, manufacturing (mainly garments for export), and commercial and residential construction. Expansion and diversification of Cambodia's drivers of growth, especially agriculture, are important development objectives for the government. Efficient transport is critical for the growth of those sectors. The agriculture sector relies on road and maritime transport for exports, the tourism sector relies on international air carriers and road transport, manufacturing relies on road and water transport to deliver the materials needed and to export finished products, and the construction sector relies on water and road transport to deliver materials.

Road transport is the largest subsector, with an estimated modal share of more than $90 \%$ for passenger and freight. The total road length in Cambodia is more than 61,000 kilometers $(\mathrm{km})$. The number of registered vehicles has been increasing at a double-digit rate each year and was more than 4 million in 2017. The number of registered motorcycles has increased by at least $10 \%$ per year since 2005 , and they accounted for about $85 \%$ of all registrations in 2017.

Railway transport is important considering its eco-friendliness and the potential for making greater use of existing railway assets. However, the modal share of railways for passenger and freight is negligible. Containers and fuel are transported on the $386 \mathrm{~km}$ Northern Line from Phnom Penh to Poipet, on the border with Thailand, and the $264 \mathrm{~km}$ Southern Line from Phnom Penh to Sihanoukville Port. Moreover, given the recent rapid urbanization and the increase in vehicles in cities, the urban transport sector should be highlighted. The country's two main international ports, Phnom Penh inland and Sihanoukville on the coast, and the three international airports, Phnom Penh, Siem Reap, and Sihanoukville, are also important infrastructure assets.

The government and development partners prepared a logistics master plan in 2018 to improve the logistics system and implement priority projects identified for realizing sustainable economic growth. ${ }^{4}$ The plan focuses on infrastructure development of roads, railways, inland waterways, ports, multimodal transport facilities, and air cargo hubs. Tourism is another important cross-subsector focus for transport infrastructure development.

4 MPWT-Japan International Cooperation Agency (JICA)-World Bank. 2018. The Study on Logistics System Improvement Master Plan in the Kingdom of Cambodia. Phnom Penh. 
The transport sector plays important roles in Cambodia's national strategic goals of promoting growth, employment, equity, and efficiency, set in the Rectangular Strategy for Growth, Employment, Equity and Efficiency, Phase IV (RSIV). ${ }^{5}$ Under the RSIV, the government aims to enhance transport connectivity and build vibrant logistics systems to enhance the competitiveness and diversification of the economy. The Industrial Development Policy, 2015-2025 requires the improvement of the transport network, especially along the industrial corridor. ${ }^{6}$ The annual national budget for transport infrastructure was $\$ 123.75$ million in 2014, $\$ 183.75$ million in 2015 , $\$ 223.04$ million in 2016 , $\$ 216.70$ million in 2017 , and $\$ 158.07$ million in 2018. ${ }^{7}$ The government is preparing an integrated multi-transport and logistics master plan.

Through the National Strategic Development Plan (NSDP), 2014-2018, the government and its development partners have planned a sector expenditure program of $\$ 910.40$ million (12\% of the NSDP budget) to improve the economy through better transport infrastructure. ${ }^{8}$

The Greater Mekong Subregion (GMS) cooperation and integration initiative has provided substantial support for Cambodia's transport sector. This ADB-supported initiative envisions an integrated, prosperous subregion based on interlinked economic corridors. The GMS Transport Sector Strategy, 2030 is designed to achieve this goal through a seamless network of transport services connecting the subregion. ${ }^{9}$ This multimodal network, which is being developed with private sector participation, is expected to give Cambodia better links and synergies across the entire GMS. ${ }^{10}$ A priority in the strategy is the upgrading of sections of the original alignment of the Southern Economic Corridor in Cambodia. The transport sector is being rehabilitated and further developed to improve access and connectivity domestically and subregionally as part of the GMS initiative, and regionally as part of the road and rail connectivity objectives of the Association of Southeast Asian Nations (ASEAN).

\section{B. Subsector Assessments}

\section{Road Transport}

Road transport is the principal mode for the movement of goods and people within Cambodia and between GMS countries. Roads are critical to social and economic development, especially in areas where they are the only available transport mode. The domestic need is to provide access between cities and to enhance rural connectivity; the regional need is to facilitate connectivity and trade within the GMS and with the economies of ASEAN.

\footnotetext{
Government of Cambodia. 2018. Rectangular Strategy for Growth, Employment, Equity and Efficiency: Building the Foundation Toward Realizing the Cambodia Vision 2050, Phase IV of the Royal Government of Cambodia of the Sixth Legislature of the National Assembly. Phnom Penh.

6 Government of Cambodia. 2015. Cambodia Industrial Development Policy, 2015-2025. Market Orientation and Enabling Environment for Industrial Development. Phnom Penh.

Government of Cambodia, MPWT. 2019. Annual Report for 2018 and Planning for 2019. Phnom Penh. Government of Cambodia. 2014. National Strategic Development Plan, 2014-2018. Phnom Penh.

ADB. 2018. GMS Transport Sector Strategy 2030: Toward a Seamless, Efficient, Reliable, and Sustainable GMS Transport System. Manila.

10 In the GMS regional investment framework, sources of finance for transport projects include development partners such as ADB and the Korea Export-Import Bank, as well as Chinese private finance of $\$ 1.6$ billion for the construction of the $190 \mathrm{~km}$ Phnom Penh-Sihanoukville Expressway.
} 
The MPWT updated the 2004 Road Development Policy in 2009, with the inclusion of a road design standard for each road class. ${ }^{11}$ In 2017, with support from the People's Republic of China (PRC), the MPWT prepared the Road Master Plan, which indicated road development priorities in the short term (2015-2020), medium term (2021-2025), and long term (2026-2030). ${ }^{12}$ In addition, Japan proposed an expressway development plan in 2013, ${ }^{13}$ while another expressway development plan was prepared with PRC support in 2014. The 2014 plan proposed the construction of a 2,230 km expressway network by 2040 with the investment of about $\$ 26$ billion. ${ }^{14}$ The integrated multi-transport and logistics master plan being prepared will include latest needs for the road sector and a comprehensive lists of road projects for investment. This road network planning aims to support the national strategic goals of promoting growth, employment, equity, and efficiency.

The MPWT prepared the Road Law, 2014 with World Bank support, covering such areas as technical regulation, road use, fund sources, inspection, and penalties. However, as of mid-2019, the law has not been effectively implemented. The government also promulgated the Road Traffic Law, 2015.

\section{a. Road Infrastructure}

The primary road network has 2,254 km of national paved roads (1-digit roads) that connect the country with its borders, the GMS, and the ASEAN network; 5,007 km of inland national roads (2-digit roads), of which $72 \%$ are paved; and 9,031 km of provincial roads (3- and 4-digit roads), of which only $30 \%$ are paved (Table 1). The MPWT is responsible for the management of national and provincial roads.

\section{Table 1: Road Sector Indicators}

\begin{tabular}{|c|c|c|c|c|c|c|c|}
\hline Road Type & $\begin{array}{l}\text { Road } \\
\text { Length } \\
(\mathrm{km})\end{array}$ & $\begin{array}{l}\text { Share in } \\
\text { Network } \\
(\%)\end{array}$ & $\begin{array}{c}\text { Roads } \\
\text { (number) }\end{array}$ & $\begin{array}{c}\text { Bridges } \\
\text { (number) }\end{array}$ & $\begin{array}{l}\text { Bridge } \\
\text { Length } \\
\text { (m) }\end{array}$ & $\begin{array}{l}\text { Paved with DBST, } \\
\text { Asphalt Concrete, or } \\
\text { Cement Concrete } \\
(\%)\end{array}$ & Agency \\
\hline National (1 digit) & 2,254 & 4 & 9 & 589 & 17,643 & 100 & MPWT \\
\hline National (2 digit) & 5,007 & 8 & 66 & 395 & 8,892 & 72 & MPWT \\
\hline Provincial ( 3 and 4 digit) & 9,031 & 15 & 528 & 1,368 & 26,032 & 30 & MPWT \\
\hline Rural & 45,242 & 74 & 15,209 & 2,128 & 30,245 & 5 & MRD \\
\hline Total & 61,534 & 100 & 15,812 & 4,480 & 82,812 & & \\
\hline
\end{tabular}

DBST = double bituminous surface treatment, $\mathrm{km}=$ kilometer, $\mathrm{m}=$ meter, MPWT = Ministry of Public Works and Transport, MRD = Ministry of Rural Development.

Sources: MPWT and MRD.

11 Based on the information from Infrastructure and Regional Integration Technical Working Group.

12 Henan Provincial Communications Planning and Design Institute Co. Ltd. 2017. Outline of Road Network Planning Project for the Kingdom of Cambodia. Zhengzhou.

13 JICA. 2013. Preliminary Data Collection Survey for Expressway Development. Tokyo.

14 Henan Provincial Communications Planning and Design Institute Co. Ltd. 2014. Outline of Expressway Development Master Plan of the Kingdom of Cambodia. Zhengzhou. 
The development needs are as follows. The 1-digit national roads with double bituminous surface treatment (DBST) need to be upgraded to asphalt concrete roads, and the lanes need to be increased from two to four to meet the increasing traffic and axle load in the sections with heavy traffic. The unpaved sections of 2-digit national roads need to be rehabilitated to meet the national standard, including paved condition (DBST or asphalt concrete). The provincial roads need to increase the paved sections. Connecting the missing links among the GMS corridors is an additional important development need.

The transport budget, which is funded by more than 10 development partners, is spent primarily on roads and bridges. During 2014-2018 the external funding sources for the national and provincial roads included the PRC (38.5\%); Japan (37.9\%); the Republic of Korea (12.0\%); and multilateral development banks (11.6\%), including ADB and the World Bank (Figure 1). Private sources of financing have been prominent in recent large road projects. ${ }^{15}$

Figure 1: Funding Source for National and/or Provincial Roads, 2014-2018 (\$ million)

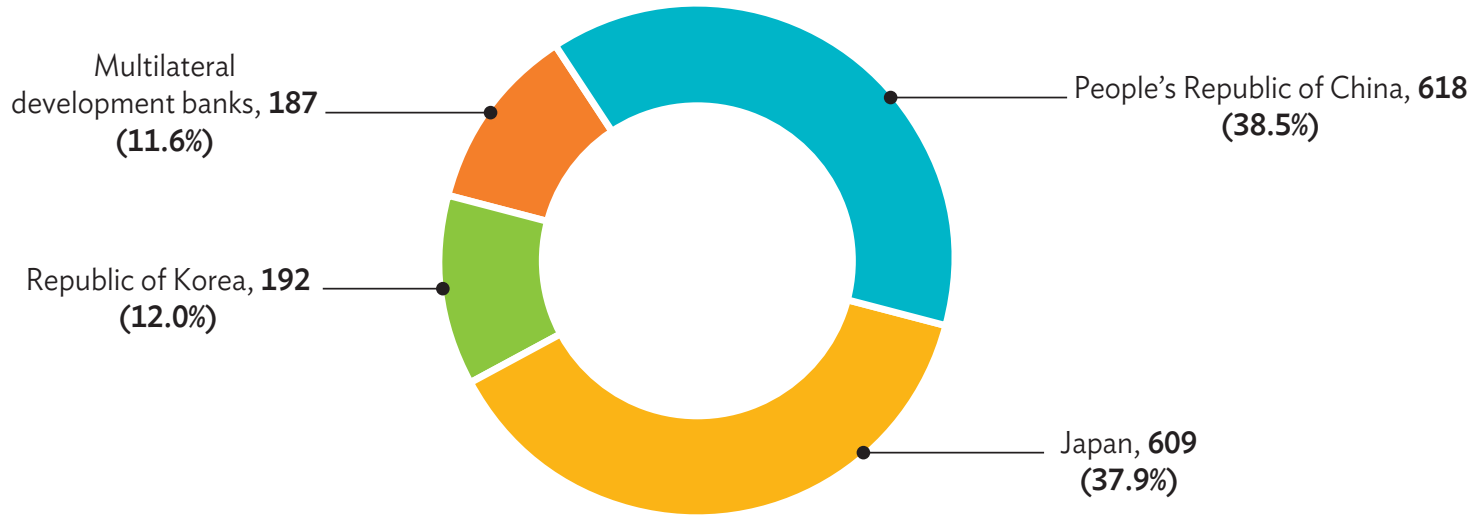

Source: Asian Development Bank estimates.

ADB is supporting the improvement of national roads through the Road Network Improvement Project (RNIP), which became effective in 2018. ${ }^{16} \mathrm{ADB}$ also supported the improvement of provincial roads through the Provincial Roads Improvement Project, which became effective in 2016. ${ }^{17}$ The main challenges related to these projects include effective design and delivery of paved roads, efficient road asset management including control of overloading, and road safety.

15 For example, construction of a build-operate-transfer expressway linking Phnom Penh to Preah Sihanouk Province financed by the private sector in the PRC is expected to start by mid-2019 with a cost of $\$ 1.8$ billion excluding expropriation costs.

16 ADB. 2017. Report and Recommendation of the President to the Board of Directors: Proposed Loan to the Kingdom of Cambodia for the Road Network Improvement Project. Manila (Loan 3576-CAM).

17 ADB. 2011. Report and Recommendation of the President to the Board of Directors: Proposed Loan to the Kingdom of Cambodia for the Provincial Roads Improvement Project. Manila (Loan 2839-CAM). 
The remaining network, consisting of about $45,241 \mathrm{~km}$ of rural roads (about $74 \%$ of the total road network), is the responsibility of the MRD. Until 2017, only about $5 \%$ of rural roads were paved with either DBST or reinforced concrete; the rest are still unpaved (laterite or earth) roads. The development need for rural roads is to upgrade unpaved roads to paved conditions, enhancing all-weather connectivity between rural economic growth centers and the national and regional road network, and promoting greater economic efficiency.

Various external financiers support the improvement of rural roads. The ADB-supported Rural Roads Improvement Project (RRIP) II, which became effective in 2014, is cofinanced by Agence Française de Développement, the Export-Import Bank of Korea, the Government of Australia, and the Nordic Development Fund. ${ }^{18}$ German development cooperation through $\mathrm{KfW}$ has been active in financing rural roads, and the Government of the PRC also has a project for improving rural roads, which became effective in 2017. The main challenges related to rural road development include incorporating climate change and/or disaster resilience, ${ }^{19}$ ensuring greater coordination with national strategic agendas such as agricultural value chain improvement, maintaining an appropriate budget for road maintenance, and internalizing effective project implementation skills.

\section{b. Road Safety}

Although great efforts were made to reduce road accidents, Cambodia's road transport fatality rate is still higher than that of neighboring countries (Figure 2). Road crashes cause suffering, fear, and trauma to victims and their families, and impose a heavy burden on the national economy. The annual economic cost of road crashes in 2013 was calculated at more than $\$ 300$ million. $^{20}$

The economic growth that accompanied road improvements triggered the use of motor vehicles despite the road users' lack of sufficient education on how to safely share the road with other users. Road safety is especially critical considering the rapid increase in and dominance of motorcycles in Cambodia (Figure 3).

Many crashes on Cambodia's roads are due to road user errors and behavioral issues such as speeding, drunk driving, driving against the traffic flow, and nonuse of motorcycle helmets. Therefore, more emphasis should be given to promoting behavior-based road safety in addition to installing traffic signs and roadside furniture. To manage road safety, the government initiated a national road safety program in 2006 to be implemented by the MPWT's National Road Safety Committee. Despite limited budget and human resources, the National Road Safety Committee strives to implement road safety programs across Cambodia.

18 ADB. 2014. Report and Recommendation of the President to the Board of Directors: Proposed Loan to the Kingdom of Cambodia for the Rural Roads Improvement Project II. Manila (Loan 3151-CAM); and ADB. 2015. Additional Financing: Proposed Administration of Loans and Grants to the Kingdom of Cambodia for the Rural Roads Improvement Project II. Manila.

19 The design features include increasing embankment heights, providing cross drainage, selecting embankment materials suitable for increased permeability, and providing hardtop surface with DBST pavement.

20 The figure is based on ADB's analysis in Appendix 15: Road Safety Enforcement in Project Communes Improved, of footnote 18. 
Figure 2: Road Fatality Rate (deaths per 100,000 population)

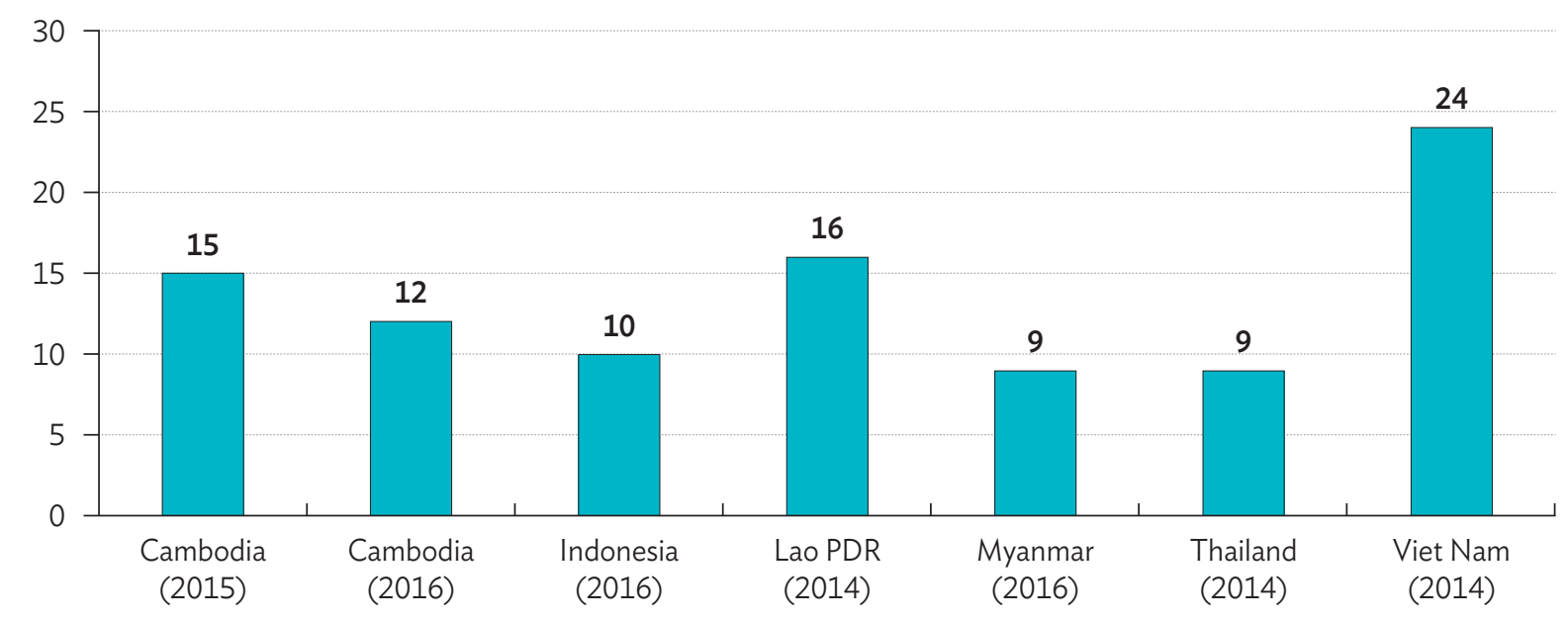

Lao PDR = Lao People's Democratic Republic.

Sources: International Road Federation; and Infrastructure and Regional Integration Technical Working Group.

\section{Figure 3: Vehicle Ownership in Cambodia}

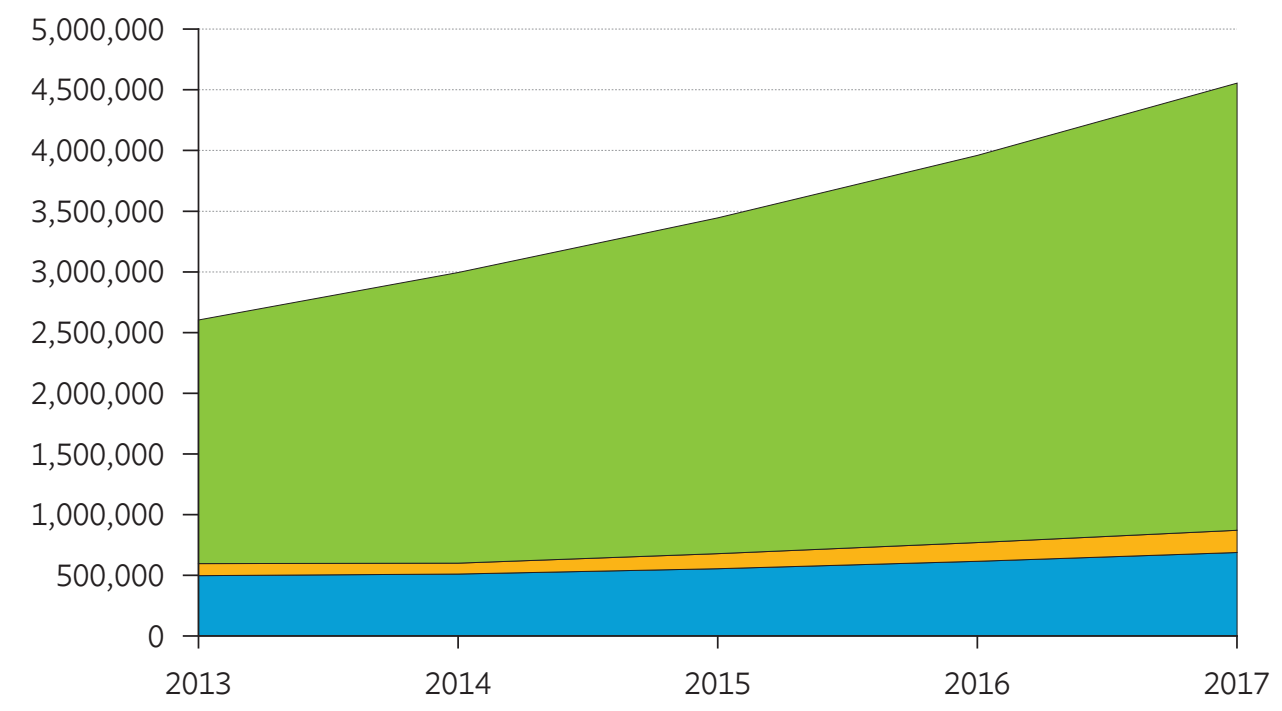

Motorcycles

$\square$ Heavy

$\square$ Light

Source: Infrastructure and Regional Integration Technical Working Group. 


\section{c. Road Asset Management}

The financial allocation for road maintenance tends to be insufficient to ensure sustainable road use. Although routine maintenance allocations increased to an appropriate level for national and provincial roads, routine maintenance for rural roads and periodic maintenance for all roads are still underfunded (Figures 4 and 5). ${ }^{21}$ Early repair of road damage such as cracks and potholes is necessary to maintain the life of the pavement. Controlling overloading is crucial to maintaining reasonable road maintenance costs. Ongoing efforts include rating of road condition through visual and mechanical inspection and analyzing maintenance requirements based on the data collected. Effective diagnosis and rehabilitation of bridges is also important considering such factors as age, size, structure, traffic volume, and maintenance frequency.

\section{Figure 4: Maintenance Budget Allocation for National and Provincial Roads (\$ million)}

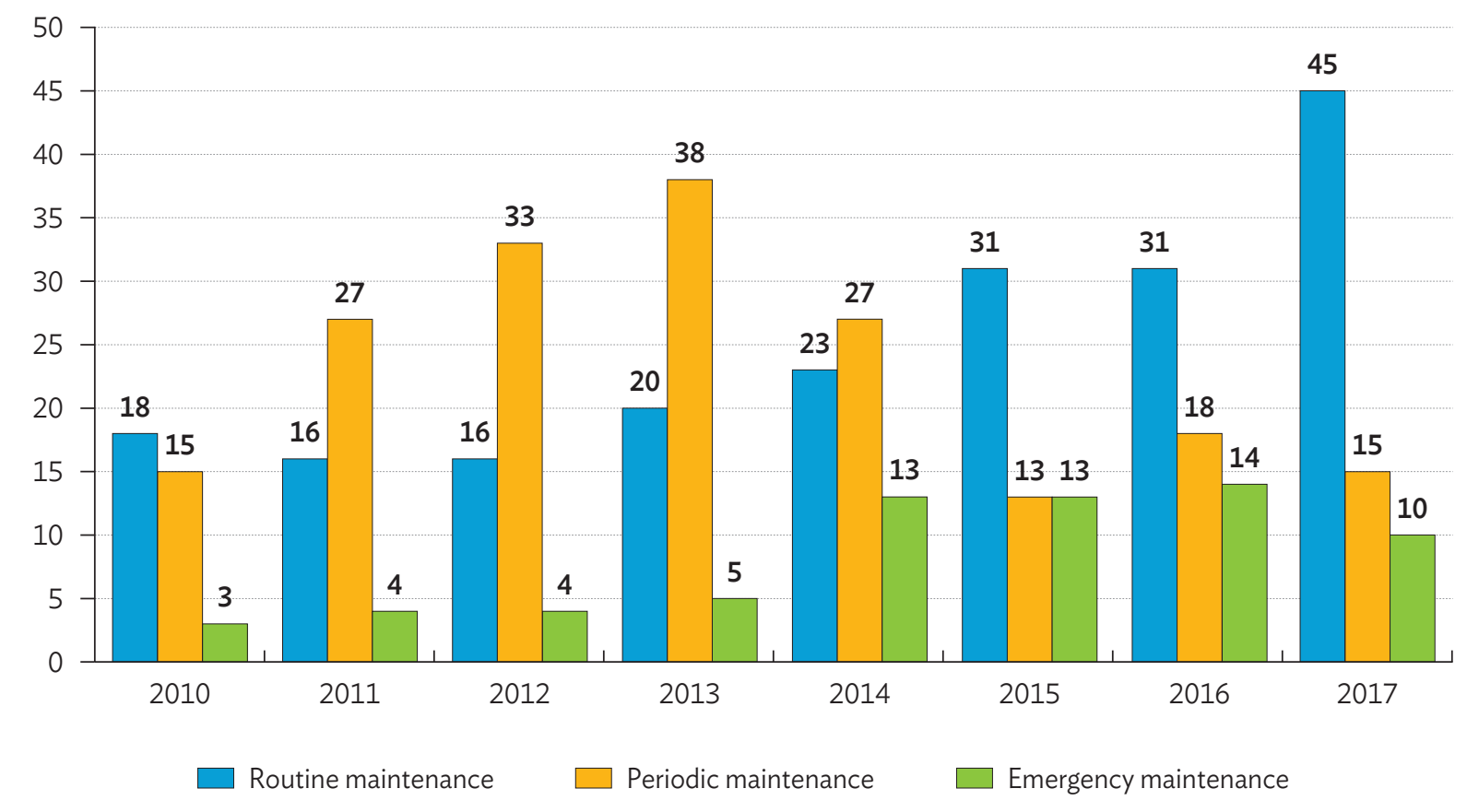

Source: Infrastructure and Regional Integration Technical Working Group.

21 For national and provincial roads, the routine maintenance budget in 2017 was about $\$ 2,800$ per $\mathrm{km}$, which seems appropriate, while the periodic maintenance budget in 2017 was about $\$ 920$ per $\mathrm{km}$, which seems insufficient assuming a requirement for periodic maintenance of at least $\$ 1,500$ per $\mathrm{km}$ per year. For rural roads, the maintenance budget in 2017 was about $\$ 440$ per $\mathrm{km}$, while the estimated need was $\$ 460$ per km considering the mixture of earth, gravel, laterite, and DBST roads. Based on this assumption, the rural road network was underfunded by about \$1 million in 2017. 


\section{Figure 5: Maintenance Budget Allocation for Rural Roads (\$ million)}

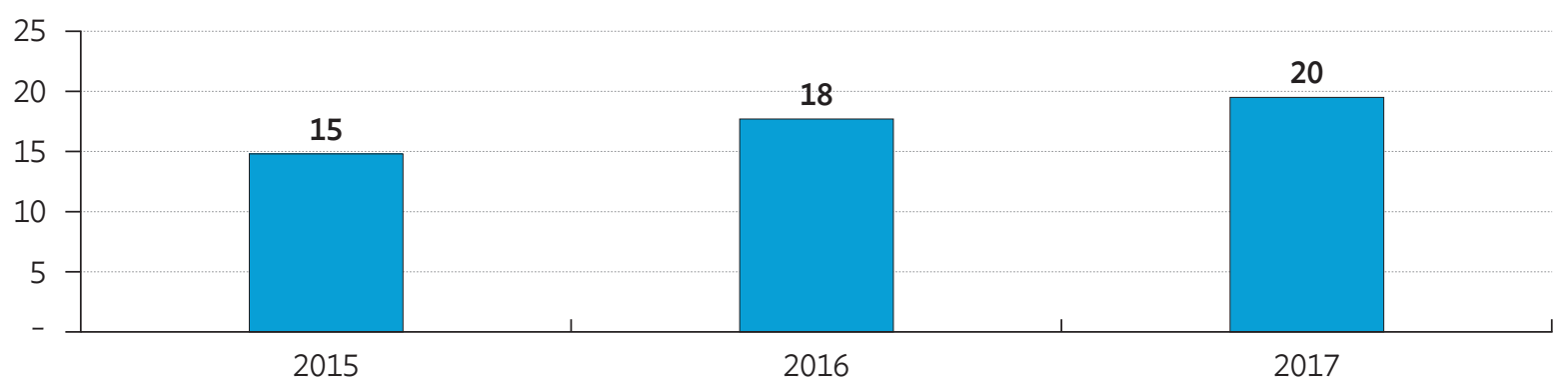

Source: Ministry of Rural Development.

For effective road asset management, MPWT introduced a performance-based maintenance contract (PBMC) for the first time in Cambodia in 2008 in the GMS Southern Coastal Corridor Project. ${ }^{22}$ The contract was successfully implemented for the duration of the contract period of 3.5 years. Since then, a hybrid form of PBMC, consisting of measurement-based payment for the rehabilitation or improvement part of the works, and performance-based payment for the maintenance part, is being applied in ADB road projects in the country. For example, the RNIP (footnote 16), which became effective in March 2018 and will rehabilitate national and provincial roads, will use the hybrid PBMC with a contract period of 4.5 years in three contract packages. For the rural roads, two hybrid PBMC packages (one international and one national) with contract periods of 5.5 and 4.5 years were awarded under the RRIP II (footnote 18). Although the hybrid PBMC is an effective approach for realizing value for money, its success will depend on the capacity of the executing agency and contractors, and their understanding of the method. ADB and the World Bank are continuing to build the capacity of the executing agencies and contractors to introduce PBMCs and implement them effectively.

\section{d. Road Transport Industry}

The trucking sector, Cambodia's major road transport industry, is fragmented. It can be classified into three segments: (i) about 20 companies, including the biggest fleet owners, organized under the Cambodian Trucking Association, own about 2,000 trucks and focus almost exclusively on international container freight business; (ii) about 90 registered companies of different sizes, most of which qualify as small and mediumsized enterprises, own 2,870 trucks; and (iii) nonregistered micro businesses and some small and mediumsized enterprises, with old vehicles that often run without registration or inspection. ${ }^{23}$ The increasing number of trucks engaging in international trade highlights the need to make border crossings more efficient, maintain road safety, and avoid overloading to maintain road quality.

22 ADB. 2017. Report and Recommendation of the President to the Board of Directors: Proposed Loans to the Kingdom of Cambodia and the Socialist Republic of Viet Nam for the Greater Mekong Subregion Southern Coastal Corridor Project. Manila.

23 ADB. 2014. Green Freight in Cambodia, Opportunities for Market-Based Interventions. Manila. 


\section{Rail Transport}

Cambodia has two railway lines with a total length of $652 \mathrm{~km}$ : the Southern Line, built between 1965 and 1969; and the Northern Line, built in the 1930s. There is also a $6.5 \mathrm{~km}$ branch line linking the Phnom Penh railway station with petroleum depot facilities along the Tonle Sap River.

Serious deterioration of the railway's infrastructure and operating conditions as a result of years of war and civil strife have led to a decline in traffic. Over the years, people have settled along the railway rights-of-way, and slum villages supporting thousands of families have sprung up along the tracks. With financial assistance from ADB, the Government of Australia, and the Organization of the Petroleum Exporting Countries (OPEC) Fund for International Development, the government embarked on a major rehabilitation project. ${ }^{24}$ Initially, this consisted of the rehabilitation of the $256 \mathrm{~km}$ Southern Line from Phnom Penh to Sihanoukville, the rehabilitation of $335 \mathrm{~km}$ of the Northern Line from Phnom Penh to Sisophon, and the reconstruction of the missing rail link from Sisophon to the Cambodia-Thailand border (about $48 \mathrm{~km}$ ) and the reestablishment of the railway connection across the border to Thailand. Because of substantial cost overruns and limited funds, the scope was reduced to rehabilitating $256 \mathrm{~km}$ of the Southern Line, $23 \mathrm{~km}$ of the Northern Line, and $42 \mathrm{~km}$ of the missing rail link from Sisophon to Poipet. The government has rehabilitated the remaining length of the Northern Line using its own resources. Freight and passenger services between Phnom Penh and Poipet commenced in July 2018. At the Poipet border with Thailand, a 1.3-km cross-border rail link connecting Poipet with Arayaprathet in Thailand was officially inaugurated in April 2019.

Assisted by $A D B$, the government undertook major policy and institutional reforms aimed at delineating commercial railway functions from public obligations and rationalizing the workforce (footnote 24). To this end, the state-owned Royal Railway was dissolved, and its assets conceded to a private operator. Under a public-private partnership (PPP), a private concessionaire was granted exclusive rights to run commercial railway services under a 30-year agreement. In turn, the concessionaire assumed the end-user risk posed by uncertain traffic development and infrastructure conditions. ${ }^{25}$ The Railway Department was established to supervise and regulate the concessionaire with respect to safety and the use of the conceded assets.

In 2013, the first year of full operation on the Southern Line, the railway carried 393,000 tons of freight, three times more than the average volume recorded before the rehabilitation project. Figure 6 shows the development of freight traffic. Containers accounted for more than $50 \%$ of the freight. Diesel fuel is the main bulk commodity. Coal has decreased in significance because an increase in the Sihanoukville Port tariff for coal caused vessels to avoid the port. Despite the significant development in traffic, the level of traffic and the average haul on the Southern Line is too low to render train operations commercially and economically viable.

24 ADB. 2006. Report and Recommendation of the President to the Board of Directors: Proposed Loan and Administration of Loan to the Kingdom of Cambodia for the Greater Mekong Subregion: Rehabilitation of the Railway in Cambodia Project. Manila (Loan 2288-CAM); and ADB. 2009. Report and Recommendation of the President to the Board of Directors: Proposed Supplementary Loan and Administration of Grant and Technical Administration Grant to the Kingdom of Cambodia for the Greater Mekong Subregion: Rehabilitation of the Railway in Cambodia Project. Manila.

25 The end-user risk includes the traffic risk and the risks accruing from the physical conditions of the facility impacting the operation and maintenance cost. In 2014, ADB estimated that the gross income from the railway operation was $\$ 3.1$ million, while the railway operation and maintenance cost was $\$ 2.3$ million. 


\section{Figure 6: Railway Freight Traffic Volume (thousand tons)}

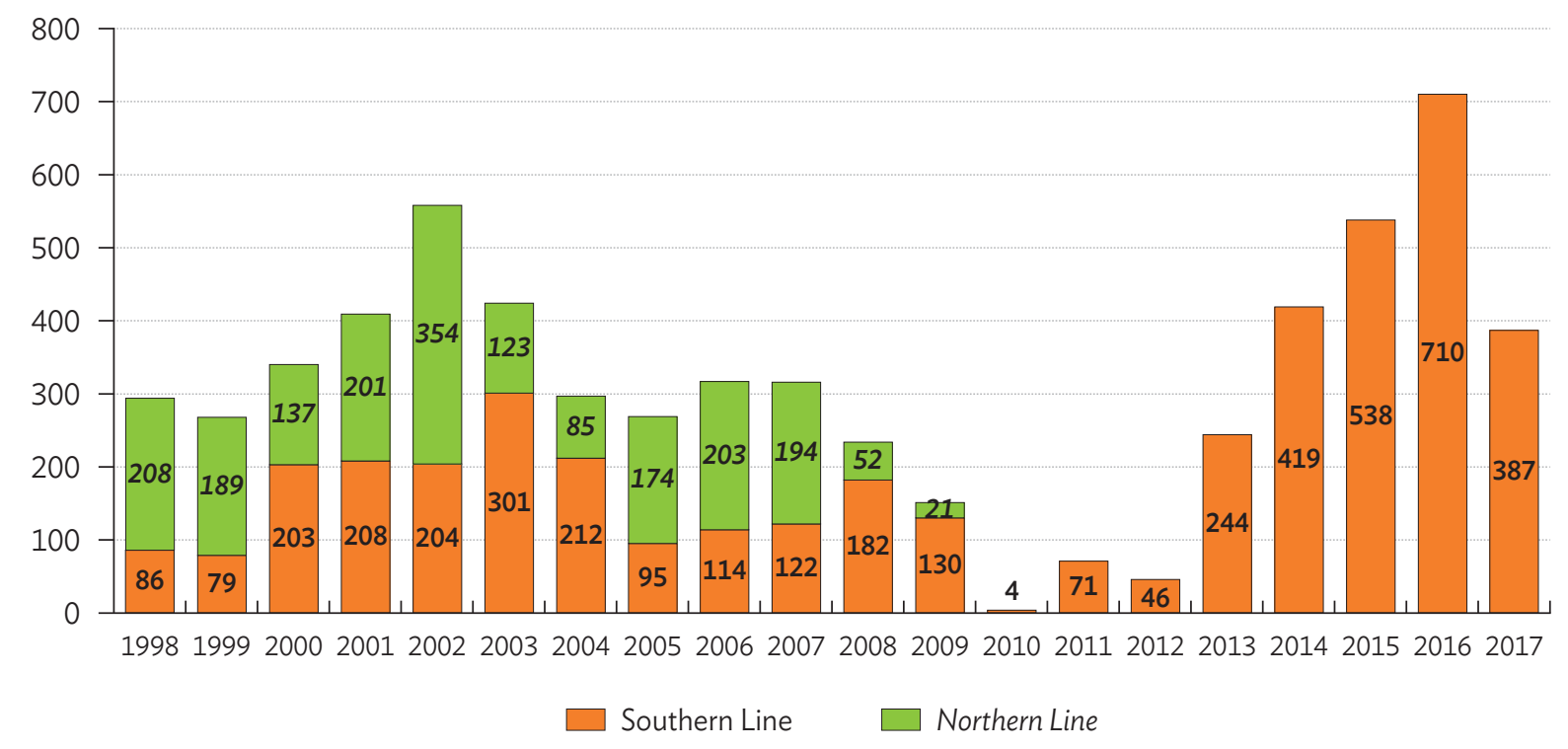

Source: Royal Railway.

The opening of the Northern Line, coupled with continued traffic growth, is a prerequisite for the future financial viability of railway operations. Passenger operations commenced in late 2017 with daily scheduled trains between Phnom Penh and Sihanoukville.

With help from the Korea International Cooperation Agency (KOICA), the government prepared a railway master plan in 2014 that provides a list of priority projects in addition to completing the pending work on the Northern Line. ${ }^{26}$ Based on this list, the government accords highest priority to the construction of

(i) a railway link from Phnom Penh to the new Phnom Penh Autonomous Port (PPAP) container terminal $35 \mathrm{~km}$ to the north;

(ii) a new $258 \mathrm{~km}$ railway link from Phnom Penh to the Viet Nam border, with an estimated cost of $\$ 1.4$ billion, including bridges totaling $20 \mathrm{~km}$ in length, which are a major contributor to the high cost; and

(iii) a multimodal logistics facility at Steung Bod on the border with Thailand, which will serve freight transport, and for which passenger services will be limited to Poipet.

26 KOICA. 2014. Master Plan for Railway Network Development in Cambodia. Phnom Penh. 
Despite the preparation of the railway master plan, there are no laws or regulations to govern railway infrastructure, operation, and technical standards and specifications. Very few trains are in operation for freight and passenger services. To better utilize the railway assets that have already been developed, operators need to be incentivized to invest in rolling stock to increase the traffic volume while ensuring safety.

\section{Urban Transport}

Cambodia is at a relatively early stage of urbanization, with only $22 \%$ of the population living in urban areas, and is significantly less urbanized than other Southeast Asian countries. ${ }^{27}$ Urban sprawl and uneven population distribution at the periphery of the cities have led to increased daily travel needs and trip frequencies. Urban transport relies overwhelmingly on private motor vehicles, and the rise in private motor vehicle ownership has resulted in growing urban congestion. Public bus transport services are limited to the main traffic arteries, making the use of private cars and other forms of motorized transport, notably tuk tuks (auto rickshaws), unavoidable even for short distances.

Cambodia's capital, Phnom Penh, has grown in area and population. In 2010, 20 communes from another province were integrated into the city, almost doubling Phnom Penh's land area. The city's population is projected to increase steadily from about 2.00 million in 2018 to 2.87 million in 2035 .

Haphazard or no zonal planning, rising traffic, and lax enforcement of traffic rules have shaped the process of urbanization. Although the government established a ministry dedicated to urban planning in 1998, the process of urbanization still appears to be unplanned and uncoordinated. The Japan International Cooperation Agency (JICA) supported the preparation of an urban transport plan for Phnom Penh in 2014, which proposed a shift from a private-oriented urban transport system to a well-balanced system of public and private transport; and a combination of road transport, public transport, and traffic management for improving citizens' mobility. ${ }^{28}$ In line with the plan, development partners have supported the installation of new buses and improvement of signalized intersections. Further development needs include installation and refinement of urban transport, such as an effective bus network system and a new urban railway system, and enhancements to the accessibility of the various transport modes.

\section{Water Transport}

Cambodia's inland waterway transport (IWT) is significant for the local economy and for the country's external trade. The Mekong River system (MRS) is a vast network of rivers, tributaries, and canals totaling 3,700 km. ${ }^{29}$

27 The figure is based on the population of Cambodia's 10 largest cities: Battambang, Kampong Cham, Kampong Speu, Phnom Penh, Prey Veng, Pursat, Siem Reap, Sihanoukville, Ta Khmau, and Takéo. Countries with advanced urbanization rates include Indonesia (53\%), the Philippines (50\%), Thailand (49\%), and Viet Nam (33\%).

28 MPWT and JICA. 2014. The Project for Comprehensive Urban Transport Plan in Phnom Penh Capital City. Phnom Penh.

29 The Mekong River accounts for about 30\% of the navigable length, the Tonle Sap River 15\%, the Bassac River 5\%, and the remaining waterways $50 \%$. However, except for the three main rivers, the waterways are restricted to shallow draft vessels of 100-150-ton capacity. (MPWT and Belgian Technical Cooperation. 2006. Master Plan for Waterborne Transport on the Mekong River System in Cambodia. Phnom Penh.) 
In the absence of roads, entire communities are dependent on IWT. In addition to its significance for rural people as a vital link between remote villages and market centers, the MRS enables trade with other countries in Southeast Asia.

Major canals were dug in the Mekong River delta during the 18th century and these networks continue to be used extensively. The canals, small rivers, and tributaries throughout the MRS are important for local boat transport and for the movement of natural resources between communities and urban areas. Upstream from Phnom Penh, natural obstructions, such as sharp bends, rapids, and shoals, impede navigation along the Mekong River, limiting traffic to small vessels and boats. In contrast, downstream from Phnom Penh to Ho Chi Minh City, the Mekong River is navigable by larger ships of up to 2,000 deadweight tons. Larger ships can pass the entrance to the Mekong only under favorable tidal conditions.

Two main ports handle Cambodia's maritime trade: the PPAP and Sihanoukville Autonomous Port (SAP). ${ }^{30}$ These ports are financially autonomous state-owned companies (i.e., they are in charge of capital investments and operation and maintenance). In 2018, the import-export volume through SAP amounted to 5,196,399 tons and 537,107 twenty-foot equivalent units (TEU), while the volume through the PPAP amounted to $12,899,000$ tons and 205,000 TEU (footnote 4). The PPAP operates two terminals - the original city terminal and a new container terminal $30 \mathrm{~km}$ southeast of Phnom Penh along the Mekong River and National Road 1. The new terminal was constructed in 2011 and achieved a turnover of 180,000 TEU of containers in 2017. The other seaports-Oknha Mong, Sre Ambel, and Koh Kong (all in Koh Kong Province)-are important for the import of goods, especially construction materials from Thailand. A state-owned operator in the PRC signed an agreement with the Government of Cambodia in April 2018 to build a new deep-sea port in Kampot Province, which is expected to accommodate large vessels of up to 30,000 tons.

The new terminal and the new international hub port of Cai Mep (south of Ho Chi Minh City in Viet Nam) changed Cambodia's trade logistics. Cai Mep's ability to accommodate the world's largest container vessels made transshipments from hub ports to feeder ports redundant. Thus, vessels from the United States and the PRC call directly at Cai Mep, avoiding a detour to Singapore, which used to be the nearest hub port in the region.

Cai Mep has become a major transshipment port for freight originating from or destined for Cambodia. This explains the rapid growth in the throughput of the new PPAP container terminal, which is reachable in 36 hours transit time to and from Cai Mep. To meet the increasing demand, the PPAP plans to increase the capacity of the new terminal to 500,000 TEU. While SAP has similar plans, it is unlikely to become a hub port and will continue to rely on feeder ships coming from hub ports, which adds an extra sector to the voyage. The development has implications for railway freight traffic. As the Royal Railway is not linked to the PPAP container terminal, it will lose container traffic to roads unless the terminal is connected to the rail network.

30 There are six other ports along the inland water ways: (i) Stung Treng Port (Stung Treng Province) located on the mainstream of the Mekong about 1,130 km up from Kratie Port; (ii) Kratie Port (Kratie Province) located on the mainstream of the Mekong $121 \mathrm{~km}$ upstream from Kampong Cham Port; (iii) Tonle Bet Port (Kampong Cham Province) located on the mainstream of the Mekong $106 \mathrm{~km}$ upstream from Phnom Penh; (iv) Neak Loeang Port (Prey Veng Province) on the mainstream of the Mekong 60 km downstream from Phnom Penh Port; (v) Chong Khneas Port (Siem Reap Province) on the Tonle Sap River 190 km upstream from Phsar Krom Port; and (vi) Phsar Krom Port (Kampong Chunang) on the Tonle Sap River 100 km upstream from Phnom Penh Port. 
Since 2006, three IWT and ports master plan studies have assessed the constraints posed to IWT and ports and recommended remedial action. ${ }^{31}$ Many of the shortcomings identified have been rectified. However, serious constraints must still be removed. The most recent master plan, prepared by KOICA, prioritized the required projects. Priority measures include dredging, improving hydrographic data and navigational aids, modernizing the fleet, and further expanding port capacity (footnote 31).

\section{Air Transport}

Cambodia's Tourism Development Strategic Plan, 2012-2020 projects that about 7 million foreign tourists will visit Cambodia annually by 2020.32 Phnom Penh International Airport can host about 5 million passengers a year and can handle 10 aircrafts simultaneously. Similarly, Siem Reap International Airport can host about 5 million passengers per year and handle eight aircrafts at a time, while Sihanoukville International Airport can host about 0.5 million passengers per year and handle four aircrafts simultaneously. The operations of these three airports are outsourced to the private sector, which is also responsible for maintenance. The State Secretariat of Civil Aviation, a government agency under the direct supervision of the Council of Ministers, is the regulator. Two new international airports are expected to be built during 2020-2030: the New Siem Reap International Airport and Dara-Sakor International Airport.

Cambodia has 10 airports, among which only three international airports are in operation. In 2017, the three international airports of Phnom Penh, Siem Reap, and Sihanoukville together handled about 9 million passengers and recorded about 90,000 aircraft movements. During 2014-2017, the passenger volume grew by $3 \%$ per year. Freight traffic was insignificant at 65,000 tons in 2017.33 Driven mainly by growth in tourist travel from the PRC, passenger traffic is likely to grow beyond 10 million by 2020.

Cambodia's air transport subsector has undergone major changes to improve its compliance with international air transport regulations and encourage private sector participation in terminal operation. To this end, the government awarded concessions to operate the main airports of the country. ${ }^{34}$ The financial collapse of Royal Air Cambodge has prompted the government to adopt an open-sky policy allowing foreign carriers to operate in Cambodia. In 2017, 42 international and domestic airlines were operating in Cambodia.

The State Secretariat of Civil Aviation is responsible for the development and management of airport facilities and the administration of aviation activities, including licensing of crew, aircraft certification for airworthiness, design of aerodromes, clearance for obstructions, and other rules to ensure safety in air travel. The secretariat also regulates the rates for the use of government airport and air navigation facilities.

31 KOICA. 2017. Master Plan Report Project for Feasibility Study on Waterway Improvement for Port Logistics Development in Cambodia. Phnom Penh; Mekong River Commission. 2015. Design of a Master Plan for Regional Waterborne Transport in the Mekong River. Phnom Penh; and Government of Cambodia, MPWT and Belgian Technical Cooperation. 2006. Master Plan for Waterborne Transport on the Mekong River System in Cambodia. Phnom Penh.

32 Government of Cambodia. 2012. Tourism Development Strategic Plan, 2012-2020. Phnom Penh.

33 The State Secretariat of Civil Aviation provided the figures quoted in this paragraph.

34 Phnom Penh International Airport is operated under a long-term concession contract ( 45 years, until 2040) by Cambodia Airports, a consortium led by Vinci Airports of France. 
During 2013-2018, completed and committed investments in the aviation subsector totaled $\$ 2,920$ million. The largest upcoming project is the replacement of the Phnom Penh International Airport with a new international airport with domestic and international terminals, for which $\$ 1,500$ million has been committed. The cost of a proposed new airport for Siem Reap is estimated at $\$ 880$ million.

\section{Logistics}

Logistics is the management of the flow of raw materials and finished goods through a transport network. The process involves a chain of defined events, activities, and infrastructure, which together determine a country's logistics performance in terms of cost, quality, and ultimately its competitiveness.

The ranking of Cambodia's logistics sector in the World Bank's Logistics Performance Index improved from 129th place in 2010 to 73rd in 2016, but dropped to 98th in 2018 (Figure 7). Cambodia's performance rating lags that of neighboring countries ${ }^{35}$ because of impediments in customs, infrastructure, logistics competence, and tracking and tracing (Figure 8).

\section{Figure 7: Logistics Performance Ranking of Cambodia and Its Neighbors, 2010-2018}

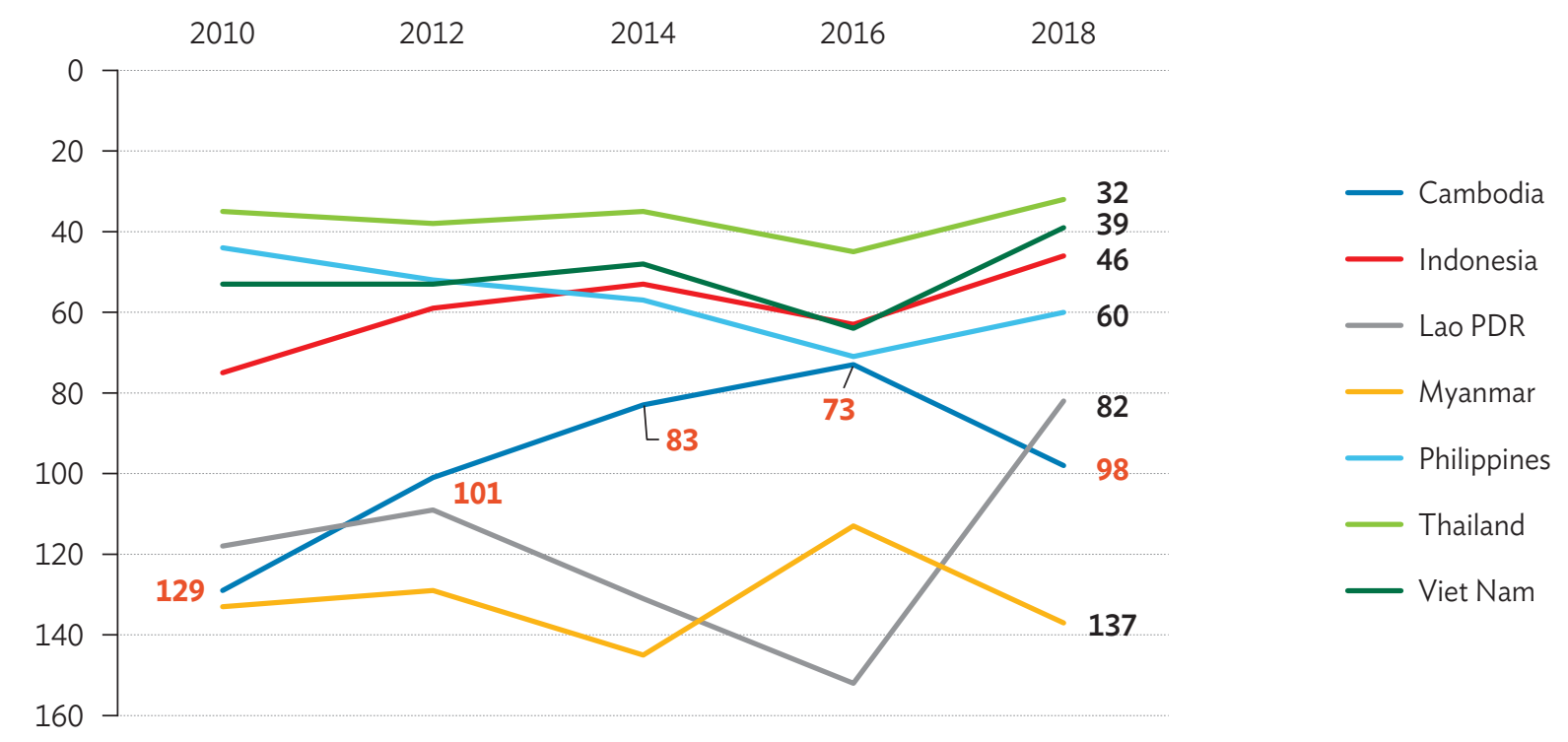

Lao PDR = Lao People's Democratic Republic.

Source: World Bank. 2018. Logistics Performance Index.

35 In 2018, Indonesia ranked 46th, the Lao People's Democratic Republic (Lao PDR) 82nd, the Philippines 60th, Thailand 32nd, and Viet Nam 39th. 


\section{Figure 8: Logistics Performance-Cambodia and Its Neighbors}
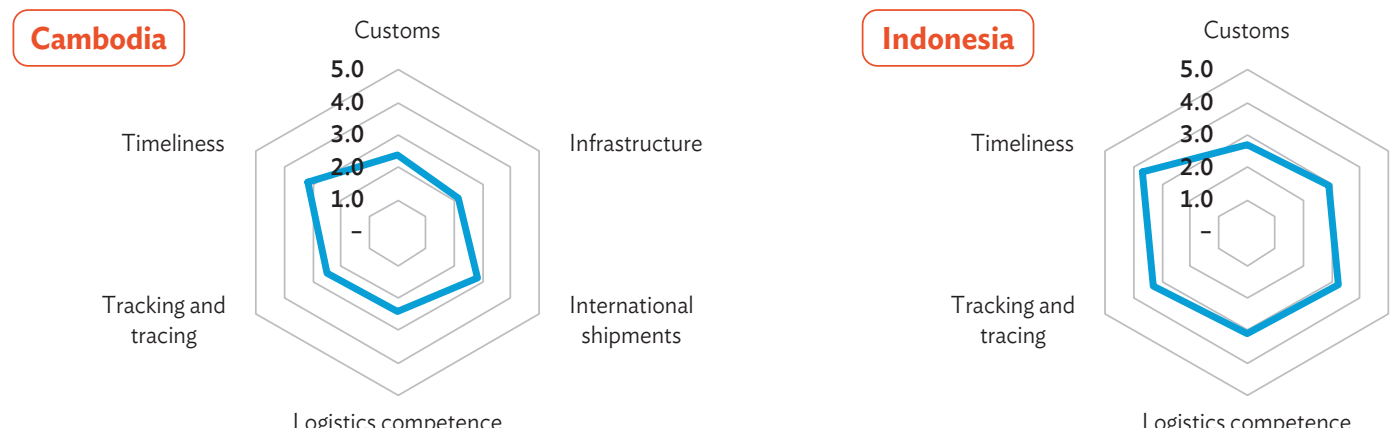

Infrastructure
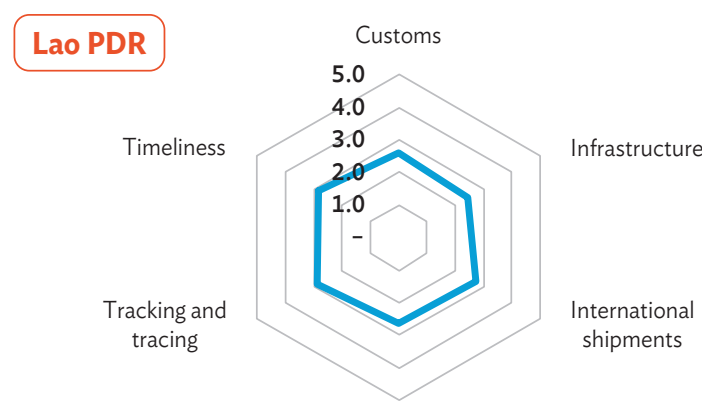

Logistics competence

shipments

Logistics competence

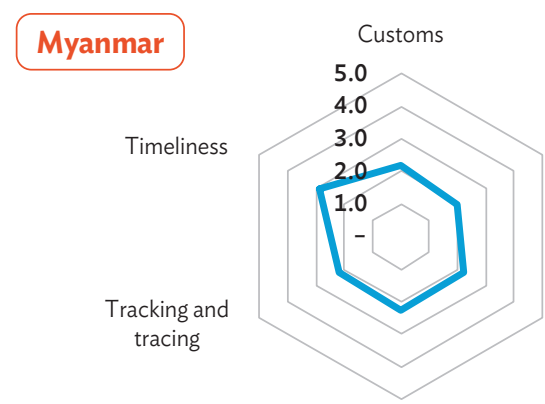

Infrastructure

Logistics competence
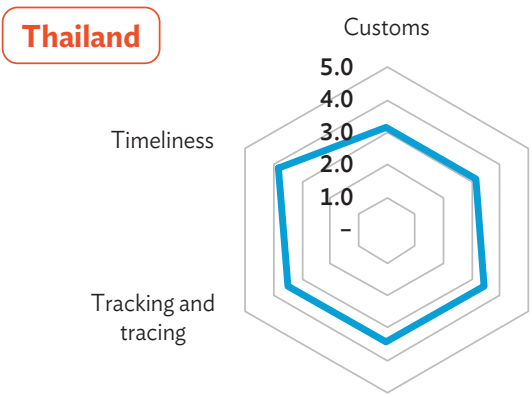

Infrastructure

Infrastructure

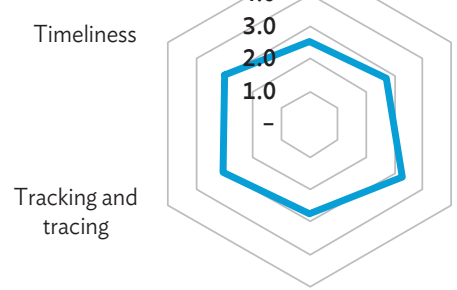

International
shipments

tracing

Logistics competence

International

shipments

Logistics competence

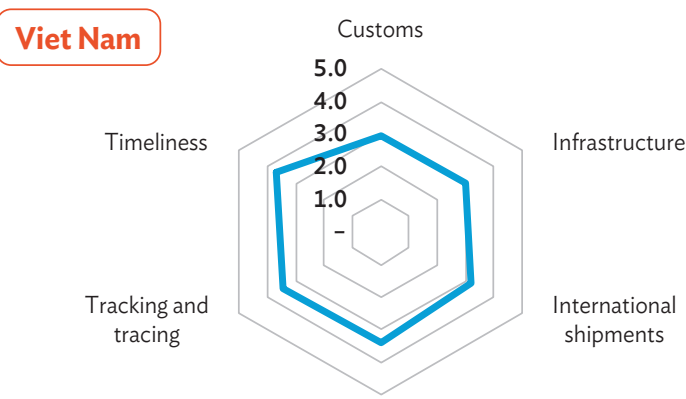

Logistics competence

Lao PDR = Lao People's Democratic Republic, LPI = Logistics Performance Index.

Notes: The 2018 LPI ranks 160 countries. The highest achievable score is 5 .

Source: World Bank. 2018. Logistics Performance Index. 
Considering that transport volumes have increased over the last 2 decades and are expected to increase further, the existing physical infrastructure is of insufficient capacity and quality. Cambodia has four major logistics hubs: the ports of Sihanoukville and Phnom Penh, and the border towns of Bavet (bordering Viet Nam) and Poipet (bordering Thailand). Sihanoukville Port serves 70\% of total exports, Phnom Penh Port accounts for $27 \%$, and Bavet and Poipet each take 3\%. Sihanoukville Port also plays a major role in imports, accounting for $66 \%$ of the total, while Poipet accounts for $13 \%$ and Bavet for $11 \%$. There are many logistics-related facilities in these four gateways, including special economic zones, inland container depots, and warehouses. Besides road and water transport, which dominate current freight movement, there may be potential to increase railway and air transport volumes by substantially improving their insufficient facilities.

Inefficient customs procedures and inadequate infrastructure constrain the logistics performance of international corridors. ${ }^{36}$ While some restrictions to cross-border traffic have been eased, operations are governed by bilateral agreements with quotas that restrict the number of trucks allowed to operate in other countries. The Cross-Border Transit Agreement provides for gradual liberalization of the quotas, yet many practical bottlenecks remain. The existing regional agreements should be fully implemented to develop an efficient regional logistics market. The government implemented the Automated System for Customs Data cargo clearance system, but not all clearance processes were computerized. For example, the computerization of import and export licenses, permits, and certificates of concerned government agencies is still under development (footnote 4).

The government formulated the Cambodia Industrial Development Policy, 2015-2025, which aims to shift the country's industrial focus to higher value-added and technology-based industry from the current concentration on light industry (footnote 6). If Cambodia can maintain a cost advantage by improving its logistics performance, higher value-added industries may attract the relocation of factories from neighboring countries. To achieve this, the government, supported by JICA and the World Bank, prepared a strategy under the Study on Logistics System Improvement Master Plan (footnote 4), which contains the following five prongs:

- Strategy 1, Development of Economic Corridors and International Gateways, aims to enhance physical connectivity with neighboring GMS countries and global markets through an improved transport network, especially in capacity and efficiency along major regional corridors such as the GMS Southern Economic Corridor and its international gateways.

- Strategy 2, Development of Logistics Hubs for Multimodal Transport, aims to enhance the functioning and efficiency of transport through seamless cross-border movement along the GMS Southern Economic Corridor, and the development of hubs to enhance logistics capacity and efficiency in urban areas and in potential regional development areas through developing a hub-and-spoke transport network concept for international gateways such as Sihanoukville, Phnom Penh, Bavet, Poipet, and Phnom Penh International Airport.

36 The major corridors include the Greater Mekong Subregion (GMS) Southern Corridor, the GMS Interlink Subcorridor (including Phnom PenhSihanoukville), and the GMS Southern Coastal Subcorridor. (World Bank. 2014. Cambodia Trade Corridor Performance Assessment. Phnom Penh.) 
- Strategy 3, Improvement of Cross-Border Management and Trade Procedures, aims for seamless border crossing through improved cross-border operations and import-export permit and inspection procedures through a Cambodia National Single Window and an ASEAN Single Window, by introducing simplification and information technology measures that comply with government requirements.

- Strategy 4, Enhancement of Private Logistics Services, aims to improve the diversity and quality of logistics services by enhancing the capacity of private logistics service providers so they can offer their customers a variety of logistics services responding to diversified requests and take action on "green logistics."

- Strategy 5, Strengthening of Legal and Institutional Framework, aims to ensure implementation of the strategies and strengthening of institutional and organizational frameworks by enhancing global agreements and the capacity of domestic institutions responsible for transport and logistics.

To implement the logistics strategy, the study has proposed 25 investment and capacity programs with a total cost of about $\$ 19$ billion (Table 2). Several of these, such as the IWT improvements, also appear under other subsector strategies. An overarching transport master plan would ensure coherence among the projects and would, therefore, be desirable.

\section{Table 2: Programs in the Logistics Strategy}

\begin{tabular}{|c|c|c|}
\hline Strategy & \multicolumn{2}{|c|}{ Program } \\
\hline $\begin{array}{l}\text { Development of } \\
\text { Economic Corridors and } \\
\text { International Gateways }\end{array}$ & $\begin{array}{l}\text { - Road Transport Capacity Enhancement } \\
\text { - Promotion of Rail Freight Transport } \\
\text { - Inland Water Transport Improvements }\end{array}$ & $\begin{array}{l}\text { - Sihanoukville Port Development } \\
\text { - Phnom Penh Port Development }\end{array}$ \\
\hline $\begin{array}{l}\text { Development of Logistics Hubs } \\
\text { for Multimodal Transport }\end{array}$ & $\begin{array}{l}\text { - Bavet Border Area Improvement } \\
\text { - Poipet Border Area Improvement } \\
\text { - Logistics Complex Development }\end{array}$ & $\begin{array}{l}\text { - Air Cargo Hub Development } \\
\text { - Urban Transport Facilitation } \\
\text { - Regional Development Support }\end{array}$ \\
\hline $\begin{array}{l}\text { Improvement of Cross-Border } \\
\text { Management and Trade } \\
\text { Procedures }\end{array}$ & $\begin{array}{l}\text { - Port Management Enhancement } \\
\text { - Introduction of Cambodia } \\
\text { National Single Window } \\
\text { - Trade Support }\end{array}$ & $\begin{array}{l}\text { - Trade Compliance Improvement } \\
\text { - Optimization of CamControl Functions } \\
\text { and Procedures }\end{array}$ \\
\hline $\begin{array}{l}\text { Enhancement of } \\
\text { Private Logistics Services }\end{array}$ & $\begin{array}{l}\text { - Establishment of a Logistics } \\
\text { Technical Training Center } \\
\text { - Public-Private Dialogue } \\
\text { - Logistics Business Modernization } \\
\text { and Green Logistics Promotion }\end{array}$ & $\begin{array}{l}\text { - Introduction of Modern Logistics } \\
\text { Business Models } \\
\text { - Market Mechanism Enhancement }\end{array}$ \\
\hline $\begin{array}{l}\text { Strengthening of Legal } \\
\text { and Institutional Framework }\end{array}$ & $\begin{array}{l}\text { - Capacity Development of } \\
\text { General Department of Logistics } \\
\text { - Development of Logistics } \\
\text { Regulatory Framework }\end{array}$ & $\begin{array}{l}\text { Facilitation of Trade Agreements } \\
\text { and Borderless Transportation } \\
\text { - Optimization of Logistics Costs }\end{array}$ \\
\hline
\end{tabular}

CamControl = Cambodia Import-Export Inspection and Fraud Repression Directorate General.

Source: Ministry of Public Works and Transport. 
Cambodia has signed and ratified all 20 GMS cross-border transport facilitation agreements (CBTAs), which contain a total of 17 annexes and 3 protocols. ${ }^{37}$ However, the CBTAs cannot be implemented yet because not all GMS countries have signed and rectified all annexes and protocols. To facilitate cross-border transport with neighboring countries, Cambodia has signed and implemented bilateral CBTAs with its three neighbors - the Lao People's Democratic Republic (Lao PDR), Thailand, and Viet Nam. The bilateral CBTA with the Lao PDR allows 40 registered vehicles to cross the border, the CBTA with Thailand allows 150 registered vehicles, and the CBTA with Viet Nam allows 500 registered vehicles.

\section{Core Sector Issues, Causes, and Effects}

The core sector problem is low connectivity and inefficiency in the transport sector (Appendix). The core sector problem stems from (i) a lack of all-weather connectivity throughout national, rural, regional, and international road networks; (ii) a lack of competitiveness resulting in high logistics costs; and (iii) unsafe and unsustainable transport infrastructure. These sector impacts have led to insufficient support for national socioeconomic development and integration into the subregional and international economy.

The following three core problems were identified for Cambodia's transport sector.

\section{Lack of refined sector policy and effective legislative implementation}

For roads, the Ministry of Public Works and Transport (MPWT) formulated the Road Development Policy in 2004, revising it in 2009 with JICA's support, and again in 2017, with support from the PRC. In addition, Japan proposed expressway development plans in 2013 and the PRC in 2014. A comprehensive and updated road sector master plan and a development strategy, including for rural roads, are being developed under the Cambodia multi-transport and logistics master plan. Meanwhile, the MPWT prepared the Road Law, 2014 with support from the World Bank, covering such areas as technical regulation, road use, fund sources, inspection, and penalties. However, the law has not been effectively implemented yet.

For railways, KOICA supported the government in preparing a railway sector master plan in 2014. However, there are no laws or regulations to govern railway infrastructure and operation, or technical standards and specifications for railways. For urban transport, JICA helped prepare an urban transport plan in Phnom Penh Capital City in 2014 (footnote 28). While pilot tests and a feasibility study are underway for a new bus system and an urban rail service in line with the master plan, the government has yet to solve such issues as effective implementation of traffic management, the institutional setting for urban transport, and enhancement of multimodal accessibility. For logistics, the strategy was prepared in 2018 with JICA and World Bank support, and 25 programs have been proposed (Table 2). Effective implementation of those programs is awaited.

37 The status is "depositing", whereby a government informs GMS member countries about protocols or annexes and notifies them when they are ready to be implemented. All GMS countries signed the Memorandum of Understanding of the Early Harvest Implementation of the CBTA (statement of the sixth meeting of the joint committee for the CBTA on 15 March 2018). 


\section{Lack of selective infrastructure investment to meet national and regional needs}

The government and development partners made significant investments in the transport sector, mainly for road improvements. Although the road sector still needs more investment, there is a clear need to focus on solving broader national and regional issues. Examples include fostering regional cooperation and integration $(\mathrm{RCl})$, tackling climate change, building climate and disaster resilience, and promoting rural development and food security by emphasizing agricultural value chain development. It is also important to diversify the investment portfolio. Key areas for effective investment will be (i) urban transport infrastructure to make cities more livable; and (ii) logistics to better manage the flow of materials and goods within the GMS and with the economies of the ASEAN.

\section{Lack of sustainability in social, environmental, and financial aspects}

Although Cambodia's road transport fatality rate has decreased, it remains high. Road safety is critical considering the rapid increase in and dominance of motorcycles. Although improved roads will bring positive social impacts for women, spurring significant transformative changes in gender relations and job creation for women in the male-dominated road construction industry is challenging. Climate change adaptation and disaster resilience are also especially important for road and other transport facilities because many of Cambodia's provinces are vulnerable to flooding. Furthermore, road maintenance tends to be underfunded. Early repair of road damage, such as cracks and potholes, is necessary to maintain the life of the pavement. Controlling overloading remains a major issue in maintaining reasonable road maintenance costs. 


\section{SECTOR STRATEGY}

\section{A. Government Sector Strategy and Plans}

The government's national strategy for growth is set out in the Rectangular Strategy for Growth, Employment, Equity and Efficiency, Phase IV (RSIV) (footnote 5). Launched in September 2018, the RSIV's objectives are to (i) ensure economic growth of $7 \%$, (ii) create more jobs, (iii) achieve the poverty reduction target of below $10 \%$, and (iv) further strengthen the capacity and governance of public institutions. The RSIV emphasizes four strategic rectangles: human resource development, economic diversification, promotion of private sector development and employment, and inclusive and sustainable development. The development need includes roads, water, electricity, and people. Under the RSIV, the government aims to enhance transport connectivity to build vibrant logistics systems to make the economy more competitive and diversified.

Through the National Strategic Development Plan, 2014-2018 (NSDP), the government and its development partners plan a sector expenditure program of $\$ 910.4$ million, or $12 \%$ of the NSDP budget, to strengthen transport infrastructure and thereby improve the economy (footnote 8 ). The NSDP emphasizes that further rehabilitation and construction of transport infrastructure is essential. In the current country context, the transport network plays a role as a prime mover of economic growth, with arteries linking all parts of Cambodia into a cohesive economic body, and is a means to integrate the national economy into the region and the world. The NSDP highlights the construction of national, provincial, and rural roads, particularly by targeting the paving of 300-400 km of additional roads per year with asphalt or concrete pavement. It also directs more attention to the repair and maintenance of the transport system, particularly roads, and to improving traffic safety.

The Infrastructure and Regional Integration Technical Working Group is a forum for the government and development partners to discuss and address transport issues and share information on transport infrastructure projects. The minister of the MPWT is the chair of the working group, and JICA serves as the group's facilitator.

To accelerate private sector participation in economic development, as envisaged in the RSIV, on 22 June 2016, the government approved the Policy Paper on Public-Private Partnerships for Public Investment Project Management, 2016-2020.38 Mechanisms approved to implement the policy include (i) setting up an interministerial steering committee to implement the policy on public-private partnerships (PPPs) and a technical working group to formulate the policy paper on PPPs for 2016-2020; (ii) defining the Action Plan, 2016-2020 and an institutional capacity and human resource development plan to manage public investment projects through PPPs; and (iii) redefining the scopes of the central PPP Unit and the Risk Management Unit of the Ministry of Economy and Finance, which were created during the fifth government mandate (2013-2018), and of a PPP unit in each sector or specialized ministry.

38 Government of Cambodia, Ministry of Economy and Finance. 2016. Policy Paper on Public-Private Partnerships for Public Investment Project Management, 2016-2020. Phnom Penh. 


\section{B. ADB Sector Support Program and Experience}

Consistent with the government's economic reform priorities, the impact of ADB's country partnership strategy (CPS) for Cambodia, 2014-2018 was the reduction in poverty and vulnerability. ${ }^{39}$ The CPSidentified two strategic pillars for ADB's activities in the country: rural-urban-regional links and human and social development; and one facilitating pillar: public sector management (PSM). The rural-urban-regional links pillar took an integrated approach to development that targeted the areas where most poor people live, and focused on transport and economic corridor development to link national value chains with the region and the world. This pillar planned to develop rural-urban-regional infrastructure (including irrigation and water management, rural electrification, rural roads, rural water supply, urban infrastructure, road maintenance, and trade facilitation) and support the commercialization of farms and competitiveness of agribusiness enterprises through improved connectivity. The human and social development pillar included secondary education, skills development, and social protection. PSM, covering decentralization and deconcentration and PSM reforms, acted as a facilitating pillar to improve country and sector governance and mitigate project-level fiduciary risks. A new CPS is being developed for 2019-2023.

ADB assistance to the country's transport sector during 1996-2018 amounted to $\$ 692.18$ million in cumulative loans, grants, and technical assistance (including cofinancing), or 19.68\% of ADB's total assistance to Cambodia (Table 3). ${ }^{40}$ These interventions focused on enhancing GMS corridors, rural development, and private sector growth. Projects received satisfactory and successful ratings. Cambodia made progress in increasing transport efficiency by reducing vehicle operating costs and travel times and supporting robust economic growth. Technical assistance projects contributed to better transport planning and policy making to improve efficiency and resource allocation. Focus areas included road transport (12 projects), rail transport (1 project), and air transport (1 project). Most of the physical outputs were rehabilitated national, provincial, and rural roads. The investments incorporated effective asset management and road safety solutions. Recent intervention promoted climate change mitigation and disaster resilience.

\section{Other Development Partner Support}

During 2005-2016, 14 multilateral or bilateral development partners provided a total of $\$ 4.12$ billion for the transport sector. Nine of these partners have funded transport infrastructure development or maintenance since 1992. Besides ADB, the following development partners are active in the transport sector: Agence Française de Développement, the Government of Australia, the Export-Import Bank of Korea, JICA, KfW, the Nordic Development Fund, the Government of the PRC, and the World Bank. Table 4 indicates development partners' support for each transport subsector and implications for ADB support.

ADB. 2014. Country Partnership Strategy: Cambodia, 2014-2018. Manila.

ADB. 2019. Asian Development Bank and Cambodia: Fact Sheet. Manila. 
Table 3: ADB Loans to the Transport Sector in Cambodia, 1996-2018

\begin{tabular}{|c|c|c|c|}
\hline Development Partner & Project & Duration & $\begin{array}{c}\text { Amount } \\
\text { (\$ million) }\end{array}$ \\
\hline \multicolumn{4}{|l|}{ Road Transport } \\
\hline$A D B$ & GMS Phnom Penh to Ho Chi Minh City Highway & 1998-2006 & 40.0 \\
\hline ADB-Australia & Primary Roads Restoration & 1999-2006 & 68.0 \\
\hline ADB-OFID & GMS Cambodia Road Improvement & $2002-2010$ & 77.5 \\
\hline ADB-Australia & GMS Southern Coastal Corridor & $2008-2013$ & 18.7 \\
\hline ADB-Australia & Road Asset Management & $2009-2013$ & 10.8 \\
\hline ADB-KEXIM & GMS Northwest Provincial Roads Improvement & $2009-2014$ & 47.9 \\
\hline ADB-KEXIM-NDF & Rural Roads Improvement & $2011-2016$ & 68.6 \\
\hline$A D B$ & Provincial Roads Improvement & $2011-2020$ & 79.3 \\
\hline ADB-KEXIM-AFD-Australia-NDF & Rural Roads Improvement II & $2014-2020$ & 192.7 \\
\hline$A D B$ & Provincial Roads Improvement-Additional Financing & $2016-2020$ & 6.0 \\
\hline$A D B$ & Road Network Improvement & $2018-2022$ & 76.7 \\
\hline$A D B$ & Rural Roads Improvement III & 2019-2025 & 66.0 \\
\hline \multicolumn{4}{|l|}{ Rail Transport } \\
\hline ADB-OFID- Australia-Malaysia & GMS Rehabilitation of the Railway in Cambodia & $2006-2013$ & 141.6 \\
\hline \multicolumn{4}{|l|}{ Air Transport } \\
\hline$A D B$ & Siem Reap Airport & $1996-2003$ & 15.0 \\
\hline
\end{tabular}

$\mathrm{ADB}=$ Asian Development Bank, AFD = Agence Française de Développement, GMS = Greater Mekong Subregion, KEXIM = Export-Import Bank of Korea, NDF = Nordic Development Fund, OFID = OPEC (Organization of the Petroleum Exporting Countries) Fund for International Development. Source: Asian Development Bank.

\section{ADB Sector Strategy}

The overall strategy is to connect transport infrastructure more strongly to growth sectors, such as agriculture, tourism, manufacturing (mainly garments for export), and commercial and residential construction, and to reach out to the rural poor by providing good all-weather road transport network to enable easier and cheaper access to markets and services. ${ }^{41}$ ADB must sustain its experience and strength in the transport sector to ensure that environmental and social safeguard standards are maintained and institutional capacity is built. A smaller number of larger, integrated projects is required, using the line ministries' skills to achieve the benefits. Development partners must be encouraged to contribute to the program. Meanwhile, the private sector must be further engaged to maintain and then accelerate the development of transport infrastructure.

41 The strategy is presented for discussion purposes only and represents no commitment on behalf of ADB or its clients. 
Table 4: Development Partner Support for Transport Subsectors

\begin{tabular}{|c|c|c|c|}
\hline Subsector/Issues & Subcategories & Development Partners & Implications for ADB Support \\
\hline \multirow{2}{*}{$\begin{array}{l}\text { National and } \\
\text { provincial roads }\end{array}$} & Master plan & JICA, PRC & \multirow{2}{*}{$\begin{array}{l}\text { ADB project (RNIP) is ongoing. } \\
\text { Further investment and policy support } \\
\text { are needed. }\end{array}$} \\
\hline & Investment & $\begin{array}{l}\text { ADB, Australia, KEXIM, Kuwait, OFID, } \\
\text { PRC, Thailand, Viet Nam, World Bank }\end{array}$ & \\
\hline Major bridges & Investment & JICA, PRC, Viet Nam & None \\
\hline Rural roads & Investment & $\begin{array}{l}\text { ADB, AFD, Australia, KEXIM, KfW, } \\
\text { PRC, World Bank }\end{array}$ & $\begin{array}{l}\text { ADB projects (RRIP II and RRIP III) are } \\
\text { ongoing. The policy context needs to } \\
\text { be updated for future interventions. }\end{array}$ \\
\hline \multirow[t]{2}{*}{ Railways } & Investment & ADB, Australia, Malaysia, OFID & \multirow{2}{*}{$\begin{array}{l}\text { Keep communicating with the } \\
\text { government for further intervention } \\
\text { opportunities. }\end{array}$} \\
\hline & Operation & Private sector & \\
\hline \multirow[t]{2}{*}{ Inland waterways } & Master plan & & \multirow{2}{*}{$\begin{array}{l}\text { Seek supporting opportunities upon the } \\
\text { government's request }\end{array}$} \\
\hline & Investment & & \\
\hline \multirow[t]{2}{*}{ Maritime ports } & Master plan & JICA & \multirow[t]{2}{*}{ None } \\
\hline & Investment & PRC & \\
\hline \multirow[t]{2}{*}{ Airports } & International & Private sector & \multirow[t]{2}{*}{ None } \\
\hline & Domestic & & \\
\hline Urban & $\begin{array}{l}\text { Master plan/ } \\
\text { Investment }\end{array}$ & JICA (for Phnom Penh) & $\begin{array}{l}\text { ADB TA is developing policy guides } \\
\text { and candidate projects to enhance } \\
\text { accessibility to public transport system. }\end{array}$ \\
\hline \multicolumn{4}{|c|}{$\begin{array}{l}\text { ADB = Asian Development Bank, AFD = Agence Française de Développement, JICA = Japan International Cooperation Agency, } \\
\text { KEXIM = Export-Import Bank of Korea, NDF = Nordic Development Fund, OFID = OPEC (Organization of the Petroleum Exporting Countries) } \\
\text { Fund for International Development, PRC = People's Republic of China, RNIP = Road Network Improvement Project, RRIP = Rural Roads } \\
\text { Improvement Project, TA = technical assistance. }\end{array}$} \\
\hline \multicolumn{4}{|c|}{ Source: ADB. } \\
\hline
\end{tabular}

Improving the GMS Southern Economic Corridor is a priority. The corridor links Cambodia with Dawei Port in Myanmar, the Bangkok Metropolitan Area in Thailand, the city of Pakxe in southern Lao PDR, and Ho Chi Minh City and Vung Tau and Quy Nhon seaports in Viet Nam (footnote 9).

ADB's ongoing and pipeline loan projects focus on national, provincial, and rural road improvement. Ongoing projects include the Rural Roads Improvement Project (RRIP) II (footnote 18), the Provincial Roads Improvement Project (footnote 17), and the Road Network Improvement Project (RNIP) (footnote 16). The RRIP III just started, following loan signing on 6 July 2018, ${ }^{42}$ and the project pipeline includes the proposed Integrated Road Network Improvement Project, which is targeted for approval in 2020.

42 ADB. 2018. Report and Recommendation of the President to the Board of Directors: Proposed Loan to the Kingdom of Cambodia for the Rural Roads Improvement Project III. Manila (Loan 3678-CAM). 
ADB's Strategy 2030, approved in July 2018, aims to achieve a prosperous, inclusive, resilient, and sustainable Asia and the Pacific (footnote 1). Support will focus on the following key operational priorities:

- addressing remaining poverty and reducing inequalities;

- accelerating progress in gender equity;

- tackling climate change, building climate change and disaster resilience, and enhancing environmental sustainability;

- making cities more livable;

- promoting rural development and food security;

- strengthening governance and institutional capacity; and

- fostering $\mathrm{RCl}$.

These priorities indicate the direction of development in Cambodia as some of them overlap with the government priorities of human resource development, economic diversification, promotion of private sector development and employment, and inclusive and sustainable development (footnote 5).

\section{Expected Results}

Figure 9 shows the strategic links with ADB's three support areas.

\section{a. Support Area 1: Refine sector policy and strengthen implementation capacity of law and regulation}

ADB's first support area is to refine sector policy and strengthen the capacity to implement laws and regulations. Although transport policies were developed for each subsector with development partner support, some need to be updated and/or integrated (e.g., the master plan in road sector, and the master plan in multimodal transport and logistics) and others need follow-up actions (e.g., the railway, urban transport, and logistics master plans) as indicated in sector problem 1. The promulgation of the Road Law, 2014 was notable; however, there have been bottlenecks in its implementation. For example, although the law defined limitation of overloading and penalties, the implementation measures, such as preparation an axle load control strategy, installation of sufficient weigh stations and mobile weigh stations, and promotion of campaigns, are yet to be done. ADB is supporting the MPWT in implementing these initiatives. In urban transport, ADB is supporting the government and Phnom Penh Capital City in developing an efficient, integrated, and sustainable urban public transport system and promoting its use by establishing transport policy guides and a planning toolkit, formulating candidate integrated urban public transport improvement programs, and providing capacity development training for better system management.

Outcome. The outcome is capability developed in refining sector policy and implementation of laws and regulations.

Outputs. The outputs are policies and master plans in transport subsectors updated, and Road Law effectively implemented by the MPWT and the MRD. 


\section{Figure 9: Strategic Links}

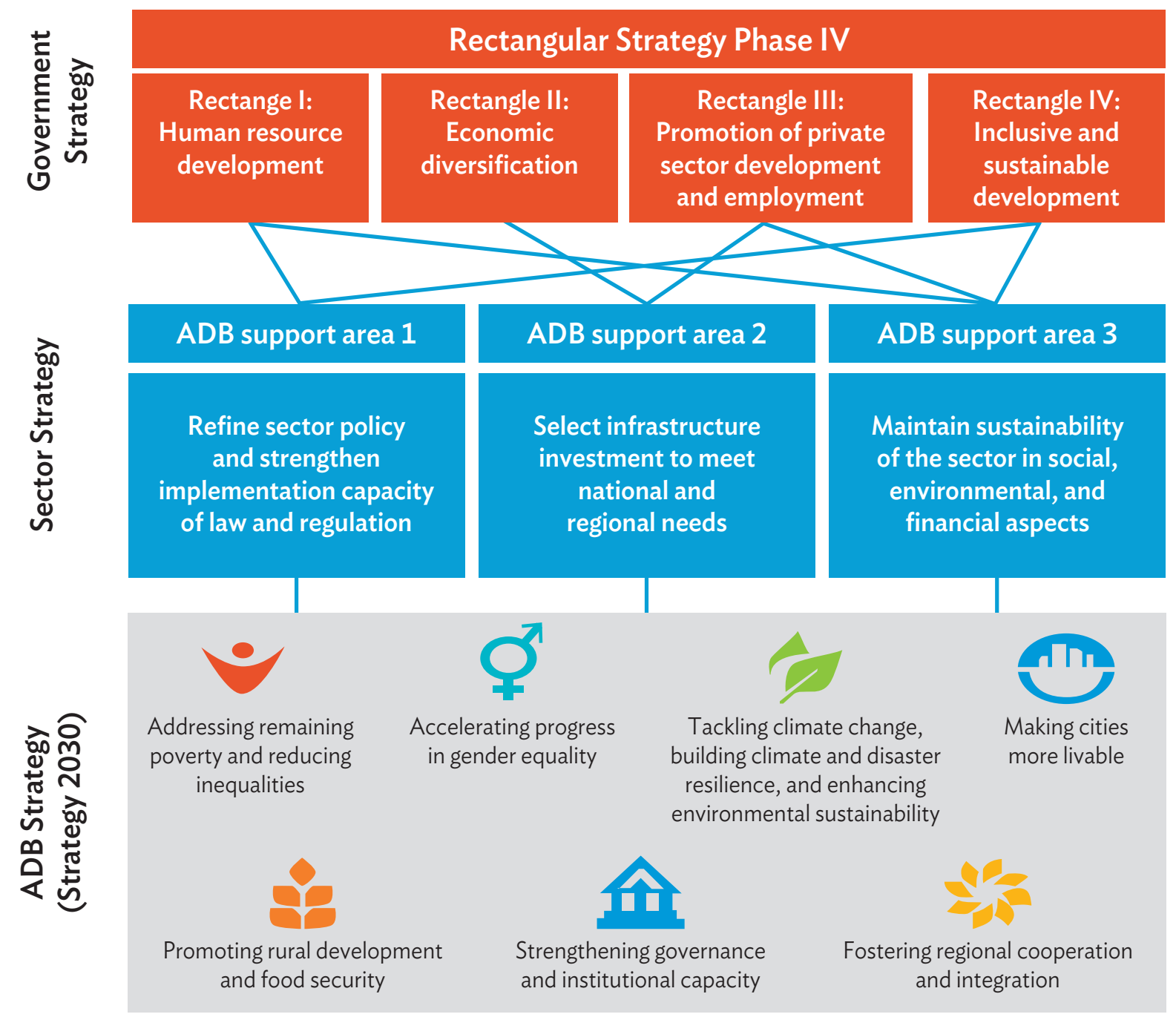

$A D B=$ Asian Development Bank.

Source: ADB.

\section{b. Support Area 2: Select infrastructure investment to meet national and regional needs}

ADB's second support area is to select infrastructure investment to meet national and regional needs. Strategy 2030 includes seven thematic priorities to guide the selection of infrastructure investment in Cambodia's transport sector (footnote 1 ). One of the priorities is fostering $\mathrm{RCl}$ to enhance connectivity in the region and the country's competitiveness. The government should prioritize the improvement of national and provincial roads with $\mathrm{RCl}$ impacts to strengthen Cambodia's strategic position in the middle of the GMS Southern 
Economic Corridor. A PPP to enhance freight flow with GMS and ASEAN countries is expected to develop the country's logistics facilities. IWT through the Mekong River system (MRS) in cooperation with the Lao PDR, Thailand, and Viet Nam is another important potential area of development.

Tackling climate change, building climate and disaster resilience, and enhancing environmental sustainability is another Strategy 2030 priority. Road improvement projects need to focus more on climate and disaster resilience because of the high flood risk in the rainy season.

Promoting rural development and food security is another ADB strategic priority. Project selection for rural road development could be considered in the context of agricultural value chain development.

Making cities more livable is a priority in ADB Strategy 2030. Although most of Cambodia's development partners have mainly financed national, provincial, and rural road projects, investment in urban transport is recommended to respond to the need to improve urban transport infrastructure and services to cope with the increased traffic in urban areas.

Outcomes. The outcomes are trade and movement of goods and services facilitated, and integration of domestic markets into the region and the world fostered.

Outputs. The outputs are transport infrastructure development and maintenance budget adequately allocated, length of paved road network increased, and urban transport infrastructure integrated.

\section{c. Support Area 3: Maintain sustainability of the sector in social, environmental, and financial aspects}

ADB's third support area is to maintain the sustainability of the social, environmental, and financial aspects of the sector. It is important to consider the gender aspects of transport projects. For example, the RRIP, a pioneer initiative for effective gender mainstreaming, created employment opportunities for women in construction work and helped shift entrenched perceptions of women's capacities. ${ }^{43}$ The establishment of the Social and Environmental Office under the MRD in 2012 proved essential for this project and for the sustainability of successful gender mainstreaming in other rural road projects in Cambodia. The Social and Environmental Office acted as a focal point for a well-coordinated project team that included project management units, provincial rural development departments, and consultants, ensuring that social and gender issues were adequately addressed during project implementation. The government should consider such favorable institutional arrangements in similar projects to ensure that gender mainstreaming efforts are sustained.

43 ADB. 2010. Report and Recommendation of the President to the Board of Directors: Proposed Loan to the Kingdom of Cambodia for the Rural Roads Improvement Project. Manila (Loan 2670-CAM). 
Because road safety continues to be a major problem, ADB should provide further assistance to ensure that the National Road Safety Action Plan achieves its objectives. These include requiring motorcycle drivers and passengers to wear helmets. Given the predominance of motorcycle accidents, motorcycle buyers should be required to present their driving license, motorcycle registration, and proof of insurance before being allowed to purchase a new motorcycle. Effective school and college bus services should also be explored to lessen the use of motorcycles for routine journeys.

The Flood Risk Management Interface, an output of the RNIP, aimed to provide easy access to information on flood impacts on Cambodia's road network. Using this interface, the MPWT will be able to evaluate risk of flood damage and climate change impacts on the network and provide guidelines for improving the resilience of roads to flooding. The RRIP and RRIP II developed a structural design for rural roads that would boost climate and disaster resilience and accommodate increasing traffic. The design involved increasing embankment heights; providing cross-drainage; selecting embankment materials suitable for increased permeability; and providing a hardtop surface made of double bituminous surface treatment (DBST) or concrete pavement. The government should apply such initiatives to other rural roads that are vulnerable to climate change and disaster risk.

Road sector investments must be preserved using an effective road maintenance regime that prolongs the life of the assets. This will also ensure sustainability of the sector. Although past and ongoing investments and technical assistance projects highlighted various initiatives, three challenges remain. First, the government should secure and maintain a sufficient budget for road maintenance. Second, a road asset management program should encourage sustainable road maintenance by incentivizing private contractors. The effectiveness of introducing performance-based maintenance contracts (PBMCs) can be studied and lessons applied for future contracts. Third, the government should institute effective control of axle loading to ensure affordable road maintenance.

Outcomes. The outcomes are social awareness in the transport sector enhanced, traffic safety improved, and environmental and financial sustainability ensured.

Outputs. The outputs are activities facilitated on gender aspects, road safety, road asset management, and enhancement of climate and disaster resilience, which will be prerequisite for the infrastructure investments.

\section{Assumptions and Risks}

The key assumption is that the government continues to accord high priority to transport infrastructure development and maintenance to support socioeconomic development in Cambodia. ADB and development partners should monitor the political direction of the new administration after the 2018 election.

The main risk is that the government's commitment to reforming the transport sector diminishes. 


\section{Timing and Resources}

To facilitate further discussion, Table 5 outlines the current and future ADB inputs to the transport sector in Cambodia.

\section{Table 5: Outline of Current and Future ADB Inputs to the Transport Sector (\$ million)}

\begin{tabular}{|c|c|c|c|c|c|c|c|c|c|c|c|c|}
\hline & 2018 & 2019 & 2020 & 2021 & 2022 & 2023 & 2024 & 20 & 25 & \multicolumn{2}{|c|}{2026} & \\
\hline Planned Key & \multicolumn{11}{|c|}{ Quarter } & Cost \\
\hline Activity Areas & \begin{tabular}{lll|}
1 & 2 & 3
\end{tabular} \mid & \begin{tabular}{l|l|l|l|} 
& 2 & 3
\end{tabular} & $\begin{array}{lll}1 & 2 & 3\end{array}$ & $1 \quad 2|3|$ & $\begin{array}{lll}1 & 2 & 3\end{array}$ & $1 \quad 2 \quad 3$ & 1223 & 12 & 34 & 1 & 2 & ADB \\
\hline
\end{tabular}

\section{Pipeline Projects}

\section{Loan Program}

1. Integrated Road Network Improvement Project

Technical Assistance Program

1. CDTA for Strengthening the Institutional Capacity of MPWT

2. KSTA for Supporting Sustainable Integrated Urban Public Transport Development

\section{Ongoing Projects}

1. Rural Roads Improvement Project II

2. Provincial Roads Improvement Project and Additional Financing

3. Road Network Improvement Project

4. Rural Roads Improvement Project III

$\mathrm{ADB}=$ Asian Development Bank, CDTA = capacity development technical assistance, $\mathrm{KSTA}=$ knowledge and support technical assistance MPWT $=$ Ministry of Public Works and Transport.

Source: ADB. 


\section{TRANSPORT SECTOR ROAD MAP AND RESULTS FRAMEWORK}

Table 6: Transport Sector Road Map and Results Framework

\begin{tabular}{|c|c|c|c|c|c|}
\hline \multicolumn{2}{|c|}{ Country Sector Outcomes } & \multicolumn{2}{|c|}{ Country Sector Outputs } & \multicolumn{2}{|c|}{ ADB Sector Inputs } \\
\hline $\begin{array}{l}\text { Outcomes } \\
\text { with ADB } \\
\text { Contribution }\end{array}$ & $\begin{array}{l}\text { Targets with } \\
\text { Indicators and } \\
\text { Baselines }\end{array}$ & $\begin{array}{l}\text { Outputs } \\
\text { with ADB } \\
\text { Contribution }\end{array}$ & $\begin{array}{c}\text { Indicators with } \\
\text { Incremental } \\
\text { Targets }\end{array}$ & $\begin{array}{l}\text { Ongoing and } \\
\text { Planned ADB } \\
\text { Operations }\end{array}$ & $\begin{array}{l}\text { Main Outputs } \\
\text { Expected from ADB } \\
\text { Interventions }\end{array}$ \\
\hline $\begin{array}{l}\text { Capability } \\
\text { developed in } \\
\text { refining sector } \\
\text { policy and } \\
\text { implementation } \\
\text { of laws and } \\
\text { regulations }\end{array}$ & $\begin{array}{l}\text { Travel share } \\
\text { of urban } \\
\text { sustainable } \\
\text { transport modes } \\
\text { (public transport } \\
\text { and bicycle) } \\
\text { increased to } 25 \% \\
\text { by } 2023 \text { (2014 } \\
\text { baseline: } 19 \% \text { ) }\end{array}$ & $\begin{array}{l}\text { Policies and } \\
\text { master plans } \\
\text { updated; } \\
\text { Road Law } \\
\text { effectively } \\
\text { implemented } \\
\text { by the MPWT } \\
\text { and the MRD }\end{array}$ & $\begin{array}{l}\text { Master plan } \\
\text { in multimodal } \\
\text { transport } \\
\text { and logistics } \\
\text { developed by } \\
2023 \text { (2017 } \\
\text { baseline: NA) }\end{array}$ & $\begin{array}{l}\text { Pipeline Projects } \\
\text { Loan Program } \\
\text { 1. Integrated } \\
\text { Road Network } \\
\text { Improvement }\end{array}$ & $\begin{array}{l}\text { Pipeline Projects } \\
\text { Loan Program } \\
\text { 1. National and provincial } \\
\text { roads improved; } \\
\text { executing agency }\end{array}$ \\
\hline \multirow{4}{*}{$\begin{array}{l}\text { Trade and } \\
\text { movement } \\
\text { of goods } \\
\text { and services } \\
\text { facilitated; } \\
\text { integration } \\
\text { of domestic } \\
\text { markets into the } \\
\text { region and the } \\
\text { world fostered }\end{array}$} & \multirow[t]{4}{*}{$\begin{array}{l}\text { Ranking on } \\
\text { the logistics } \\
\text { performance } \\
\text { index improved } \\
\text { to } 65 \text { th by } 2023 \\
\text { ( } 2016 \text { baseline: } \\
73 \text { rd) }\end{array}$} & \multirow{2}{*}{$\begin{array}{l}\text { Transport } \\
\text { infrastructure } \\
\text { development } \\
\text { and } \\
\text { maintenance } \\
\text { budget } \\
\text { adequately } \\
\text { allocated }\end{array}$} & \multirow{2}{*}{$\begin{array}{l}\text { Public } \\
\text { expenditure on } \\
\text { transport from } \\
\text { government and } \\
\text { development } \\
\text { partners' funding } \\
\text { increased to } 3.0 \% \\
\text { of gross domestic } \\
\text { product by } 2023 \\
(2016 \text { baseline: } \\
1.9 \%)\end{array}$} & & $\begin{array}{l}\text { capacity strengthened, } \\
\text { including for road asset } \\
\text { management and } \\
\text { road safety }\end{array}$ \\
\hline & & & & \multirow{3}{*}{$\begin{array}{l}\text { TA Program } \\
\text { 1. Strengthening } \\
\text { the Institutional } \\
\text { Capacity of the } \\
\text { MPWT } \\
\text { 2. Supporting } \\
\text { Sustainable } \\
\text { Integrated } \\
\text { Urban Public } \\
\text { Transport } \\
\text { Development }\end{array}$} & \multirow{3}{*}{$\begin{array}{l}\text { TA Program } \\
\text { 1. MPWT's institutional } \\
\text { and regulatory } \\
\text { frameworks } \\
\text { strengthened, strategic } \\
\text { framework for engaging } \\
\text { the private sector in } \\
\text { road maintenance } \\
\text { established, and } \\
\text { axle overload } \\
\text { control operations } \\
\text { strengthened } \\
\text { 2. Urban public transport } \\
\text { policy developed, } \\
\text { urban transport } \\
\text { accessibility and } \\
\text { connectivity improved, } \\
\text { and capacity and } \\
\text { awareness improved }\end{array}$} \\
\hline & & $\begin{array}{l}\text { Length of paved } \\
\text { road network } \\
\text { increased }\end{array}$ & $\begin{array}{l}\text { Share of } \\
\text { paved roads in } \\
\text { total network } \\
\text { increased to } 20 \% \\
\text { by } 2023(2018 \\
\text { baseline: } 18 \%)\end{array}$ & & \\
\hline & & $\begin{array}{l}\text { Urban transport } \\
\text { infrastructure } \\
\text { integrated }\end{array}$ & $\begin{array}{l}\text { Integrated } \\
\text { urban transport } \\
\text { infrastructure } \\
\text { project identified } \\
\text { and financed } \\
\text { by } 2023 \text { ( } 2017 \\
\text { baseline: NA) }\end{array}$ & & \\
\hline
\end{tabular}


Table 6: Continued

\begin{tabular}{|c|c|c|c|c|c|}
\hline \multicolumn{2}{|c|}{ Country Sector Outcomes } & \multicolumn{2}{|c|}{ Country Sector Outputs } & \multicolumn{2}{|c|}{ ADB Sector Inputs } \\
\hline $\begin{array}{l}\text { Outcomes } \\
\text { with ADB } \\
\text { Contribution }\end{array}$ & $\begin{array}{c}\text { Targets with } \\
\text { Indicators and } \\
\text { Baselines }\end{array}$ & $\begin{array}{l}\text { Outputs } \\
\text { with ADB } \\
\text { Contribution }\end{array}$ & $\begin{array}{l}\text { Indicators with } \\
\text { Incremental } \\
\text { Targets }\end{array}$ & $\begin{array}{l}\text { Ongoing and } \\
\text { Planned ADB } \\
\text { Operations }\end{array}$ & $\begin{array}{l}\text { Main Outputs } \\
\text { Expected from ADB } \\
\text { Interventions }\end{array}$ \\
\hline $\begin{array}{l}\text { Social awareness } \\
\text { in transport } \\
\text { sector enhanced, } \\
\text { traffic safety } \\
\text { improved; } \\
\text { environmental } \\
\text { and financial } \\
\text { sustainability } \\
\text { ensured }\end{array}$ & $\begin{array}{l}\text { Road traffic } \\
\text { fatalities } \\
\text { reduced to } \\
3.00 \text { per } 10,000 \\
\text { vehicles by } 2023 \\
(2017 \text { baseline: } \\
4.30)\end{array}$ & $\begin{array}{l}\text { Activities } \\
\text { facilitated on } \\
\text { gender aspects, } \\
\text { road safety, } \\
\text { road asset } \\
\text { management, } \\
\text { and } \\
\text { enhancement } \\
\text { of climate } \\
\text { and disaster } \\
\text { resilience }\end{array}$ & $\begin{array}{l}\text { Axle load } \\
\text { control strategy } \\
\text { developed and } \\
\text { implemented } \\
\text { by } 2023 \text { (2017 } \\
\text { baseline: NA) }\end{array}$ & $\begin{array}{l}\text { Ongoing Projects } \\
\text { 1. Rural Roads } \\
\text { Improvement } \\
\text { Project II } \\
\text { 2. Provincial } \\
\text { Roads } \\
\text { Improvement } \\
\text { Project } \\
\text { 3. Road Network } \\
\text { Improvement } \\
\text { Project } \\
\text { 4. Rural Roads } \\
\text { Improvement } \\
\text { Project III }\end{array}$ & $\begin{array}{l}\text { Ongoing Projects } \\
\text { 1. Rural roads improved, } \\
\text { rural roads asset } \\
\text { management } \\
\text { enhanced, rural road } \\
\text { safety and community } \\
\text { awareness program } \\
\text { implemented, } \\
\text { project management } \\
\text { supported, and } \\
\text { connectivity for the } \\
\text { Mekong River islands } \\
\text { improved } \\
\text { 2. Project roads and } \\
\text { cross-border facilities } \\
\text { rehabilitated; } \\
\text { MPWT road asset } \\
\text { management } \\
\text { improved; road safety, } \\
\text { institutional efficiency, } \\
\text { and awareness of } \\
\text { potential social } \\
\text { problems increased; } \\
\text { resilience of project } \\
\text { roads to climate change } \\
\text { increased; project } \\
\text { management efficient } \\
\text { 3. Safer and climate } \\
\text { resilient national roads } \\
\text { delivered, axle load } \\
\text { control enhanced, } \\
\text { quality assurance for } \\
\text { civil works in MPWT } \\
\text { strengthened, and road } \\
\text { safety enforcement } \\
\text { in project communes } \\
\text { improved } \\
\text { 4. 360 km of rural roads } \\
\text { improved, rural road } \\
\text { asset management } \\
\text { improved, and } \\
\text { awareness of road } \\
\text { safety and potential } \\
\text { social problems } \\
\text { strengthened }\end{array}$ \\
\hline
\end{tabular}

$\mathrm{ADB}=$ Asian Development Bank, $\mathrm{km}=$ kilometer, MPWT = Ministry of Public Works and Transport, MRD = Ministry of Rural Development, $N A=$ not applicable,$T A=$ technical assistance.

Source: Asian Development Bank. 


\section{APPENDIX}

\section{PROBLEM TREE FOR TRANSPORT SECTOR}

\begin{tabular}{|c|c|c|c|c|c|c|}
\hline National & \multicolumn{6}{|c|}{ Insufficient support for national socioeconomic development and integration into subregional and international economy } \\
\hline $\begin{array}{l}\text { Sector } \\
\text { impacts }\end{array}$ & \multicolumn{2}{|c|}{$\begin{array}{l}\text { Lack of all-weather connectivity } \\
\text { throughout national, rural, regional, } \\
\text { and international road networks }\end{array}$} & \multicolumn{2}{|c|}{$\begin{array}{l}\text { Lack of competitiveness resulting } \\
\text { in high logistics costs }\end{array}$} & \multicolumn{2}{|c|}{$\begin{array}{l}\text { Unsafe and unsustainable } \\
\text { transport infrastructure }\end{array}$} \\
\hline $\begin{array}{l}\text { Core sector } \\
\text { problem }\end{array}$ & \multicolumn{6}{|c|}{ Low connectivity and inefficiency in the transport sector } \\
\hline $\begin{array}{l}\text { Core } \\
\text { problems }\end{array}$ & \multicolumn{2}{|c|}{$\begin{array}{l}\text { Lack of refined sector policy and } \\
\text { effective legislative implementation }\end{array}$} & \multicolumn{2}{|c|}{$\begin{array}{l}\text { Lack of selective infrastructure investment } \\
\text { to meet national and regional needs }\end{array}$} & \multicolumn{2}{|c|}{$\begin{array}{l}\text { Lack of sustainability in social, } \\
\text { environmental, and financial aspects }\end{array}$} \\
\hline $\begin{array}{l}\text { Sector } \\
\text { problems, } \\
\text { risks, and } \\
\text { assumptions }\end{array}$ & $\begin{array}{l}\text { Sector } \\
\text { Problems } \\
\text { - Formal transport } \\
\text { policies not } \\
\text { prioritized } \\
\text { - Lack of strategy } \\
\text { for project } \\
\text { prioritization } \\
\text { - Insufficient } \\
\text { coordination of } \\
\text { transport sector } \\
\text { planning } \\
\text { - Implementation } \\
\text { of law } \\
\text { insufficient } \\
\text { (e.g., Road Law) } \\
\text { Capacity } \\
\text { building for } \\
\text { a long-term } \\
\text { sequenced } \\
\text { process } \\
\text { Greater Mekong } \\
\text { Subregion } \\
\text { (GMS) border } \\
\text { agreements for } \\
\text { road not yet } \\
\text { implemented } \\
\text { GMS border } \\
\text { agreements } \\
\text { for rail not } \\
\text { complete } \\
\text { - Private sector } \\
\text { laws and } \\
\text { regulations } \\
\text { required }\end{array}$ & \begin{tabular}{l}
\multicolumn{1}{c}{ Risks and } \\
Assumptions \\
- Lack of focus \\
on policy \\
requirements \\
- Professional \\
training not \\
institutionalized \\
- Trained staff \\
not retained \\
- Cross-border \\
agreements \\
with \\
neighboring \\
countries \\
insufficient \\
- Private sector \\
transport \\
investment \\
exceeds \\
capacity of \\
government \\
and \\
development \\
partners
\end{tabular} & $\begin{array}{l}\text { Sector } \\
\text { Problems } \\
\text { - Lack of } \\
\text { sufficient } \\
\text { pavement for } \\
\text { national and } \\
\text { provincial roads } \\
\text { to meet traffic } \\
\text { demand } \\
\text { - Lack of paved } \\
\text { and all-weather } \\
\text { access of local } \\
\text { road network } \\
\text { Incomplete } \\
\text { GMS physical } \\
\text { facilities } \\
\text { Lack of } \\
\text { emphasis on } \\
\text { multimodal } \\
\text { facilities } \\
\text { Lack of urban } \\
\text { public transport } \\
\text { Lack of } \\
\text { accessibility in } \\
\text { public transport } \\
\text { Lack of } \\
\text { mechanism for } \\
\text { competition, } \\
\text { transparency, } \\
\text { and } \\
\text { accountability } \\
\text { in procurement } \\
\text { process and } \\
\text { operations for } \\
\text { public-private } \\
\text { partnership } \\
\text { projects }\end{array}$ & \begin{tabular}{l}
\multicolumn{1}{c}{ Risks and } \\
Assumptions \\
- Low \\
coordination \\
among \\
development \\
partners for \\
investment \\
planning \\
- Poor transport \\
conductivity \\
across \\
international \\
borders, and \\
cross-border \\
facilities not \\
developed \\
Slow and \\
inefficient \\
project \\
implementation \\
Private sector \\
not attracted to \\
infrastructure \\
development
\end{tabular} & \begin{tabular}{l}
\multicolumn{1}{c}{ Sector } \\
Problems \\
- Lack of \\
maintenance \\
system of \\
national and \\
local road \\
network \\
- Insufficient \\
private sector \\
involvement \\
- Persistent \\
poor traffic \\
engineering \\
and operations \\
along national \\
highway \\
network \\
Poor prevention \\
of traffic \\
overloading \\
Inadequate and \\
lack of proper \\
implementation \\
of traffic \\
safety devices, \\
hardware, and \\
measures \\
- Poor driver \\
and pedestrian \\
behavior \\
Inadequate and \\
inconsistent \\
application of \\
safeguards
\end{tabular} & $\begin{array}{l}\text { Risks and } \\
\text { Assumptions } \\
\text { - Lack of } \\
\text { transparency } \\
\text { in civil works } \\
\text { bidding } \\
\text { - Lack of } \\
\text { capacity and } \\
\text { quality control } \\
\text { of contractors } \\
\text { and } \\
\text { consultants } \\
\text { Insufficient } \\
\text { mitigation of } \\
\text { unsafe road } \\
\text { conditions } \\
\text { Persistent } \\
\text { poor road user } \\
\text { behavior } \\
\text { Poor } \\
\text { enforcement } \\
\text { of traffic laws } \\
\text { and regulations } \\
\text { Poor driver } \\
\text { licensing } \\
\text { and vehicle } \\
\text { inspection } \\
\text { processes } \\
\text { Inadequate } \\
\text { support from } \\
\text { motorcycle } \\
\text { manufacturers }\end{array}$ \\
\hline
\end{tabular}

Source: Asian Development Bank. 


\section{Cambodia Transport Sector Assessment, Strategy, and Road Map}

Cambodia's transport sector plays a critical role in the country's economic development by supporting growth in key sectors such as agriculture, tourism, manufacturing, and construction. This publication examines Cambodia's transport sector performance, major development constraints, and the government's strategy and plans. It also reflects on lessons learned from past Asian Development Bank (ADB) assistance and identifies potential areas for future support, including knowledge initiatives and investments.

The publication serves as a basis for further dialogue on how ADB and the government can collaborate to effectively develop the transport sector in the coming years.

\section{About the Asian Development Bank}

ADB is committed to achieving a prosperous, inclusive, resilient, and sustainable Asia and the Pacific, while sustaining its efforts to eradicate extreme poverty. Established in 1966, it is owned by 68 members -49 from the region. Its main instruments for helping its developing member countries are policy dialogue, loans, equity investments, guarantees, grants, and technical assistance. 